\title{
Whole-Rock Geochemistry and Mineralogy of Triassic Montney Formation, Northeastern British Columbia, Western Canada Sedimentary Basin
}

\author{
Edwin I. Egbobawaye \\ Department of Earth and Atmospheric Sciences, University of Alberta, Edmonton, Canada \\ Email: edwinegboba@gmail.com
}

Received 31 October 2015; accepted 26 January 2016; published 29 January 2016

Copyright (C) 2016 by author and Scientific Research Publishing Inc.

This work is licensed under the Creative Commons Attribution International License (CC BY).

http://creativecommons.org/licenses/by/4.0/

(c) (7) Open Access

\begin{abstract}
Inductively Coupled Plasma-Mass Spectrometry (ICP-MS) was used to analyze chemical elementsmajor, trace and rare earth elements (REE) concentrations, augmented with quantitative X-ray diffraction (XRD) analysis and thin-section petrography for mineralogical characterization of the Triassic Montney Formation in northeastern British Columbia, Western Canada Sedimentary Basin (WCSB). Results from this study indicate that integration of chemical elements with mineralogy shows affinity to the host lithologies. Evidently, chemical elements are the building blocks for minerals, thus, their significances in the interpretation of geological systems are unambiguous. Herein, major elements concentration such as $\mathrm{Al}, \mathrm{Fe}, \mathrm{K}, \mathrm{Mg}, \mathrm{Ca}, \mathrm{Mn}$ in the samples analyzed from the Montney Formation are interpreted as: 1) indication of dolomitization and diagenesis; 2) trace elements-Rb, Th, $U$, and Cs are related to the organic matter-kerogen in the clay component of the Montney Formation source rock; and 3) transition metals-Sc, V, Co, Cr, Zn show strong affinity with diagenesis in the study interval.
\end{abstract}

\section{Keywords}

Geochemistry, Whole-Rock, Mineralogy, Montney Formation, Thin-Section, Petrography, Trace-Elements, ICP-MS, XRD, Dolomitization, Diagenesis, WCSB

\section{Introduction}

The term trace element in geochemistry refers to chemical elements whose concentration is less than 1000 ppm or $0.1 \%$ of a rock's composition [1] [2], and concentration greater than the aforementioned values refers to ma- 
jor elements (expressed as weight \% oxides, each $>0.1 \%$ ). Elements make up a large portion of the earth's crust, but occur most often as minerals [3]. Elements such as carbon, hydrogen, nitrogen, oxygen, phosphorus, calcium, sulphur, and iron are the principal chemical elements that living organisms utilize in their body tissues for reproduction, energy, and their daily functional activities [4]. The geological significances of these elements are related to being components of the oceans, atmosphere, and as building blocks for minerals, and crustal rocks. As a result, whole-rock element geochemistry is invaluable in understanding the chemical, physical, and geological forces that continually redistributes these elements between living and non-living reservoirs through biogeochemical cycles [4]. Whole-rock chemical element geochemistry is useful in chemostratigraphic correlations, and have been used to decipher the physical and chemical mechanisms, and interpretation of diverse geological systems [5].

The understanding of the variability and affinity of these chemical elements in rocks have led to the identification of chemical signatures in many sedimentary basins of various tectonic regimes [5]. Furthermore, wholerock element composition provides a means of quantification and calibration of the concentration of chemical elements with mineralogy, thereby giving additional information about host rock lithology and accessory minerals. Whole-rock elements geochemistry can help to decode the interrelationship between components of the oceans, crustal rocks, biogeochemical systems [4], seawater $\mathrm{pH}$, and atmospheric $\mathrm{CO}_{2}$ concentrations spanning centuries, or even millions of years [6]. Many paleoclimatic studies have utilized chemical elements such as Aluminum (Al), Manganese (Mn), and Barium (Ba) concentrated in the rock record to unravel paleoclimate and tectonic regimes [5] [7]-[9]. These studies have led to better understanding of the changes that causes chemical weathering in source areas and help to show the variation in climatic changes in ancient rocks on a geological time scales [10] [11]. The application of whole-rock elements geochemistry are numerous in geological interpretation, thus its utility in the study of Triassic Montney Formation.

Stratigraphically, the Montney Formation is the basal stratigraphic unit of Triassic succession in the subsurface of western Canada (Figure 1 and Figure 2). It rests, unconformably upon Belloy Formation-carbonate strata of Permian age [12]-[16]. The succession was deposited in a west-facing, arcuate extensional basin on the western margin of Pangaea [16]-[18]. The Montney Formation consists of siltstone, very fine-grained sandstone, bioclastic packstone/grainstone-coquina, in Alberta [15] [16] [19], interlaminated, interbedded, dolomitic silty-sandstone and rich in organic matter [20]. The intervals composed of fine-grained sandstones within the Montney Formation is the hydrocarbon reservoir. Previous studies of the Montney Formation in Western Canada Sedimentary Basin (WCSB) have mainly focused on sedimentology, regional stratigraphy, biostratigraphy, and ichnology [12] [16]-[18] [21]-[28]. Other workers study the tectonics of WCSB, e.g., [27] [29]-[31], and oil and gas reservoir of the Montney Formation have been assessed, e.g., [13] [19] [20] [32][35]. Despite numerous previous work, however, no work has been published in the journal that utilized chemical elements integrated with mineralogy and petrography to interpret the Montney Formation dolomitization and diagenesis.

This paper evaluate the Triassic Montney Formation dolomitization and diagenesis using chemical elements whole-rock geochemistry coupled with whole-rock mineralogy and thin-section petrography in order to better understand the Montney Formation dolomitization and diagenesis.

\section{Geological Setting}

Based on analyses of paleomagnetic data, paleolatitude and paleoclimatic zonation [37], and fauna record [38], the Western Canada Sedimentary Basin (WCSB) during the Triassic time was situated at approximately $30^{\circ} \mathrm{N}$ paleolatitude [37]. The paleoclimate reconstruction suggests that the paleoclimate may have ranged from sub-tropical to temperate [24] [30] [37] [38]. The region has been interpreted to be arid during the Triassic, and was dominated by westerly winds from the west [12] [37] [39].

The WCSB forms a northeast thinning wedge of sedimentary rocks with thickness of more than 6000 meters, which extends southwest from the Canadian Shield into the Cordilleran foreland thrust belt [24] [40]. The Cordilleran of the WCSB provides the evidence that the origin and development of the basin was associated with tectonic activity attributed to episodes of epeirogenic subsidence; [24] [40]-[42]; this is interpreted to be post Triassic, especially due to mountain influences [24] [43] and [44] interpreted sediment loading as evidenced by deformed beds, slump structures and small-scale faults as indicators of tectonic influences on the deposition of Triassic successions. Within the Foothills and Rocky Mountain Front Ranges, Triassic rocks were subjected to Jurassic-Cretaceous Columbian and Upper Cretaceous-Lower Tertiary Laramideorogenies, which caused series 
of imbricate thrust faults and folds in the region [12] [45].

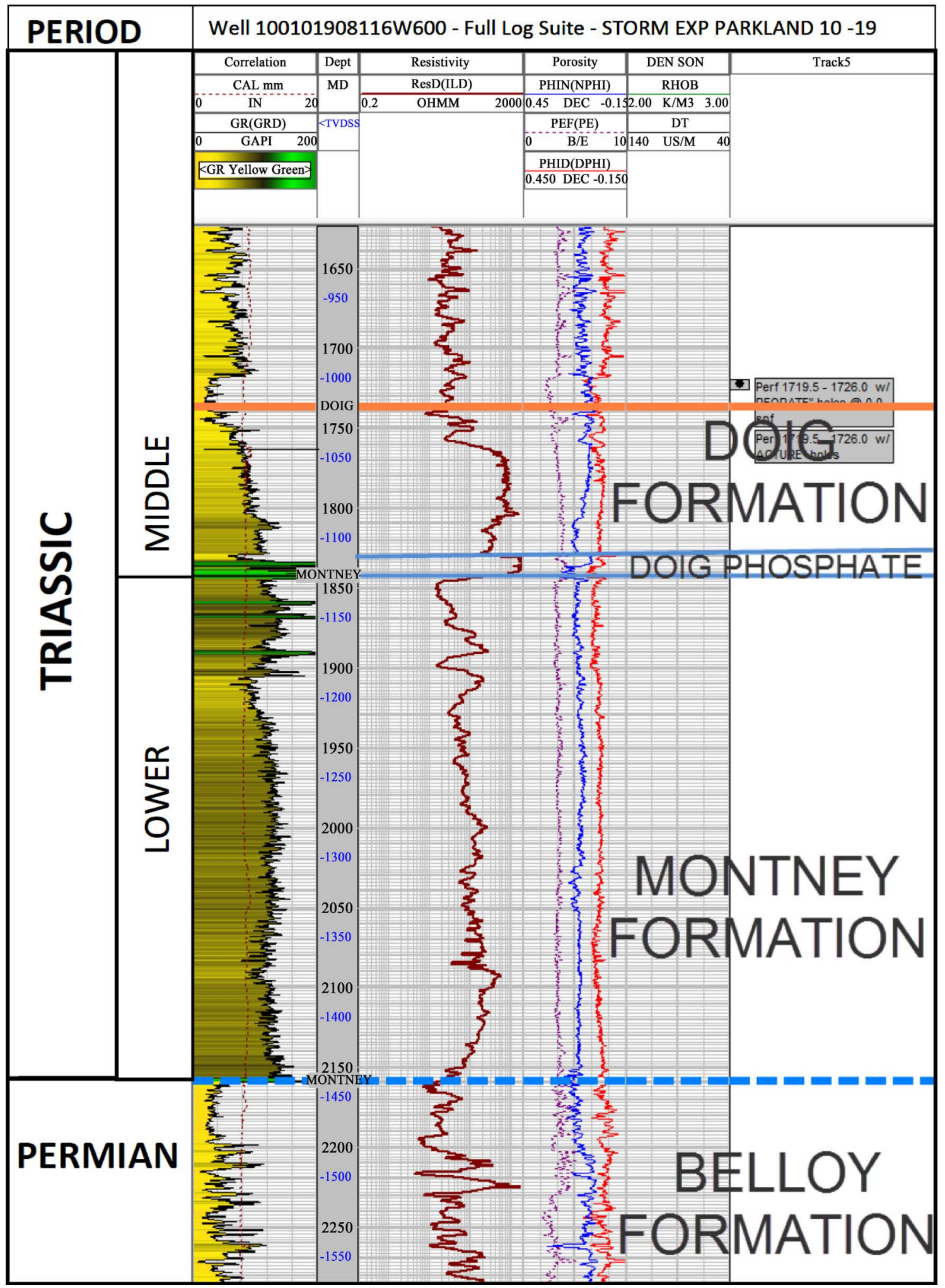

Figure 1. Type log of the Montney formation in the study area, northeastern British Columbia, western Canada sedimentary basin (WCSB). 
In Alberta and British Columbia, Triassic sediments were deposited in a central sub-basin known as the Peace River Embayment, which extended eastward from the Panthalassa western ocean onto the North American craton [12]. During the Triassic period, the Peace River Embayment was a low mini basin associated with minor fault block movement caused by a broad downwarp, which resulted in the rejuvenation of structural deformation within the Monias areas of southwest Fort St. John, British Columbia [12] [45].

The Triassic succession thickened westward [12], and rests unconformably in most areas, upon the Belloy Formation in outcrop of northeastern British Columbia; Carboniferous in parts of northeastern British Columbia and Alberta; and Fantasque Formation in outcrop at Williston [36]. The thickness of the Montney Formation within the Fort St. John area (max: 320 meters thick) in the subsurface (Figure 3), varies in the east along Brit-

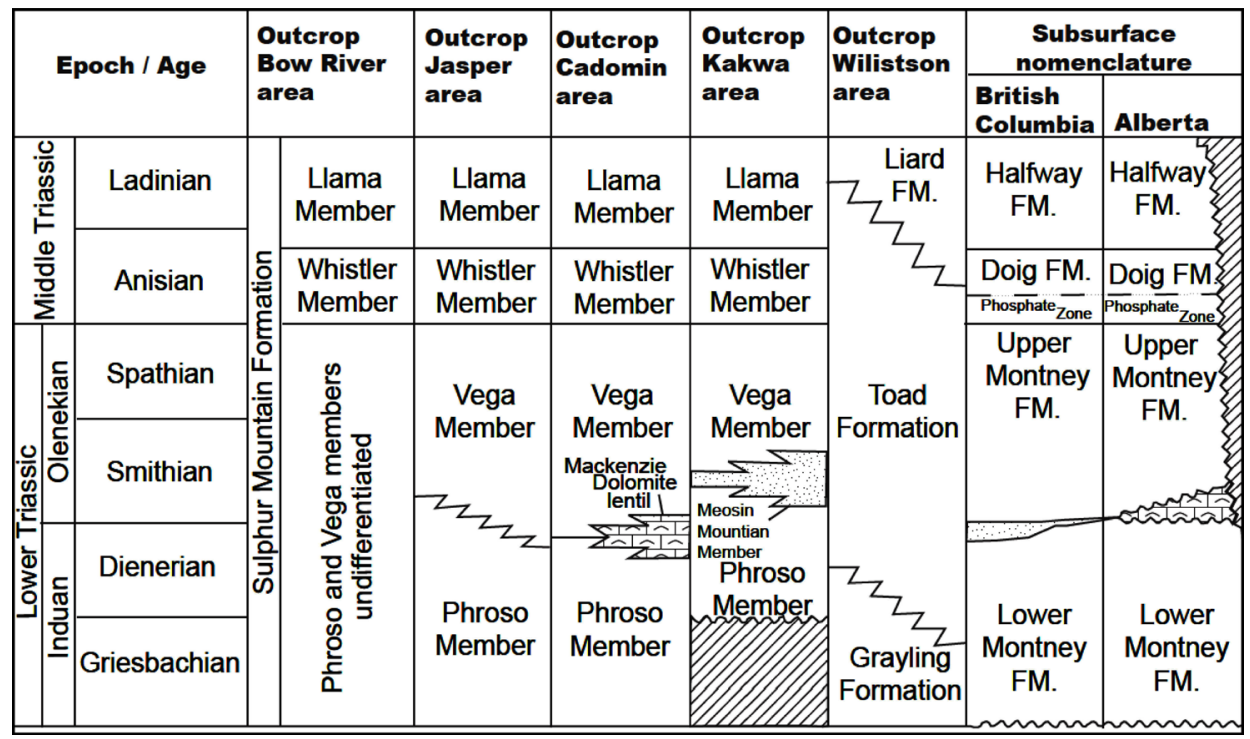

Figure 2. Stratigraphic chart showing lower and middle Triassic deposits and a corrrelation of outcrop with coeval subsurface strata in the western Canada sedimentary basin; modified from [36].

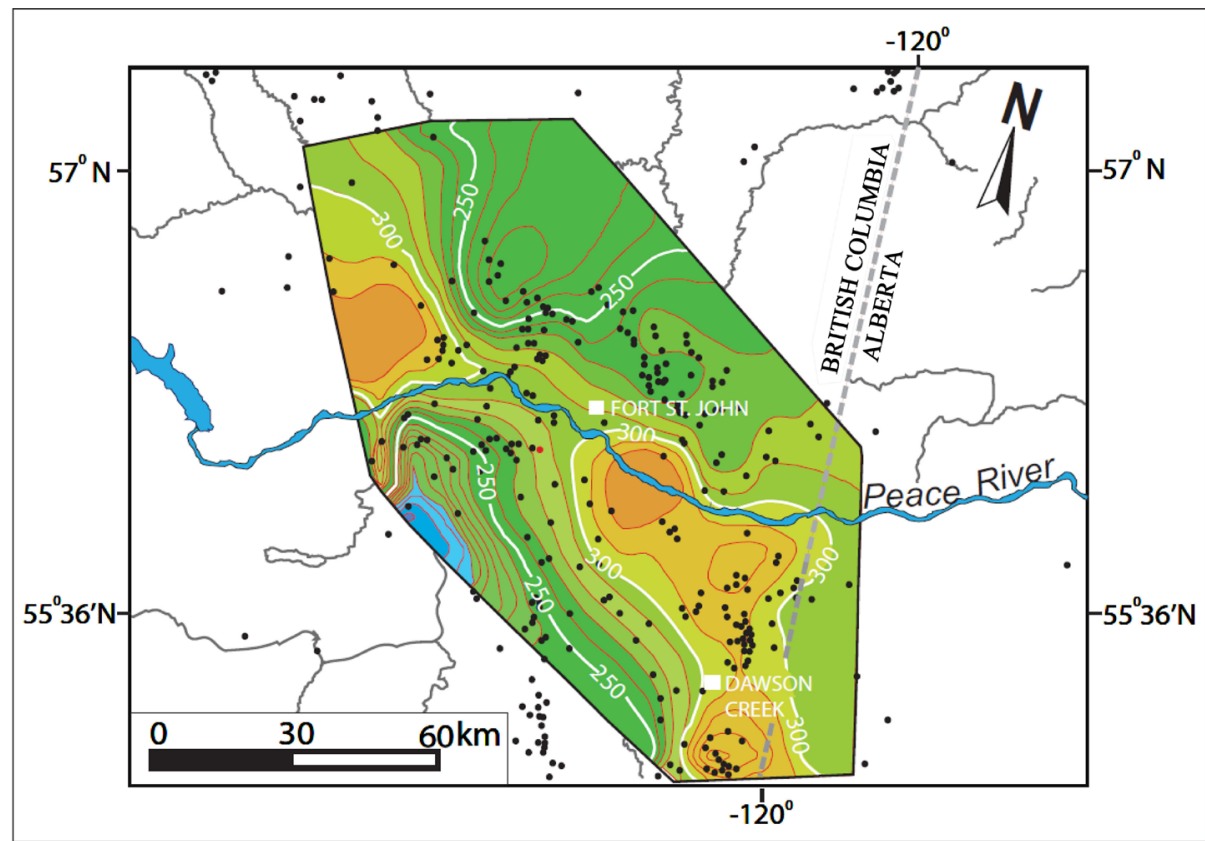

Figure 3. Isopach map of the Montney Formation tight-gas reservoir in the study area showing depositional trends and thickness in northeastern British Columbia, Western Canada Sedimentary Basin (WCSB). 
ish Columbia/Alberta boarder boundary and to the western portion of British Columbia [20]. The Montney Formation structure map indicates higher paleostructure in the east and low in the western portion of the study area [20]. The structural tilt shows a depositional thinning to the east and north due to erosional removal [12].

\section{Method of Study}

Rock samples collected from drill cores from five wells in northeastern British Columbia were crushed into powder using pulverizing shatter-box machine at the University of Alberta. Samples were assayed for wholerock chemical elements geochemical analysis using Inductively Coupled Plasma-MassSpectrometry (ICP-MS) technique at the University of Alberta Lab. Sample requirement is approximately $\pm 5 \mathrm{ml}$ for ICP-MS measurements. The machine can rapidly determine over 70 elements (Table 1 ) in $<2 \mathrm{ml}$ of sample solution in less than 2 minutes [46]. The functionality of the instruments are based on the principle that by viewing the appropriate region in an Ar plasma tail flame, the atomic and ionic emission lines of analytes can be measured against very low background emissions intensities [46]. The method can show nearly all elements present in a sample (Table 1).

Quantitative X-ray diffraction (XRD) analysis was used to determine whole-rock mineralogy of the Montney Formation (Table 2). XRD is essential in the study of fine-grained sediments because it allows moderately accurate determination of the amount of minerals present in a sample, particularly, magnesium substitution in calcite or dolomite lattices [47], thus helping to decipher dolomitization and diagenesis.

Thin-sections were examined with petrographic microscope in accordance with the method of thin-section petrography [48] to determine textural characteristics, mineralogical composition, evidence of dolomitizationand diagenesis. Traditional thin-section examination technique was used to determine grain-size, sorting, roundness, and mineralogy (Figure 4).

\section{Results}

Chemical elements analyzed in the Montney Formation are grouped into three categories, based on their concentration: 1) major rock-forming mineral elements ( $\mathrm{Al}, \mathrm{Ca}, \mathrm{Fe}, \mathrm{K}, \mathrm{Mg}, \mathrm{Mn}, \mathrm{Na}, \mathrm{Si}$ ) have the highest concentration (Table 1); 2) trace elements such as $\mathrm{Ag}, \mathrm{Ba}, \mathrm{Cd}, \mathrm{Co}, \mathrm{Cr}, \mathrm{Mo}, \mathrm{Ni}, \mathrm{Pb}, \mathrm{Sn}, \mathrm{Sr}, \mathrm{V}$, etc., have low concentration compared to major elements (Table 1 and Figure 5 and Figure 6); and 3) rare earth elements (Figure 7), or Lanthanides, which comprises La, Ce, Pr, Nd, Pm, Sm, Eu, Gd, Tb, Dy, Ho, Er, Tm, Yb, Lu elements (Figure 7).

The integration of chemical elements with mineralogy shows affinity to the host lithologies. Evidently, chemical elements are the building blocks for minerals, thus, their relevance in the interpretations of geological system is unambiguous. Based on data in Table 1, major elements concentrations of $\mathrm{Al}, \mathrm{Fe}, \mathrm{K}, \mathrm{Mg}, \mathrm{Ca}, \mathrm{Mn}$ in the samples analyzed are interpretedas indication of dolomitizationand diagenesis while trace elements- $\mathrm{Rb}, \mathrm{Th}, \mathrm{U}$, and Cs are related to the organic matter-kerogen in the clay component of the Montney Formation source rock, and transition metals-Sc, V, Co, Cr, Zn show strong affinity with diagenesis in the study interval. The highest level of dolomitization in the Montney Formation occur at the depths of $2042 \mathrm{~m}$ and $2055.2 \mathrm{~m}$ with magnesium/calcite concentrations (Table 1 ) in the amount of 42,120 ppm/90,976ppm and 48,152 ppm/98,597ppm respectively.

The concentration of quartz mineral (wt.\%) in whole-rock mineralogy data-set is a predictor of calcite and dolomite concentration (Table 2). High quartz concentration yields corresponding low calcite/dolomite concentrations and vice-versa.

\subsection{Mineralogy}

Whole-rock analysis of bulk mineralogy (Table 2) of the Montney Formation shows that quartz is the dominant mineral by percent volume and abundance, followed by calcite, and then dolomite. Clay total volume in the Montney Formation is relatively high (outside of the study area), but lower than quartz, and in some interval clay is higher than the volume of dolomite and calcite (Table 2). However, within the study area (Figure 2), clay content is relatively low. Feldspar, plagioclase, and pyrite constitute significant component of the Montney Formation. Apatite and marcasite only occur as trace (very low by percent volume). Apatite in particular, is related to the Montney/Doig phosphate zone. To exemplify the mineralogical transformation in the Montney For- 


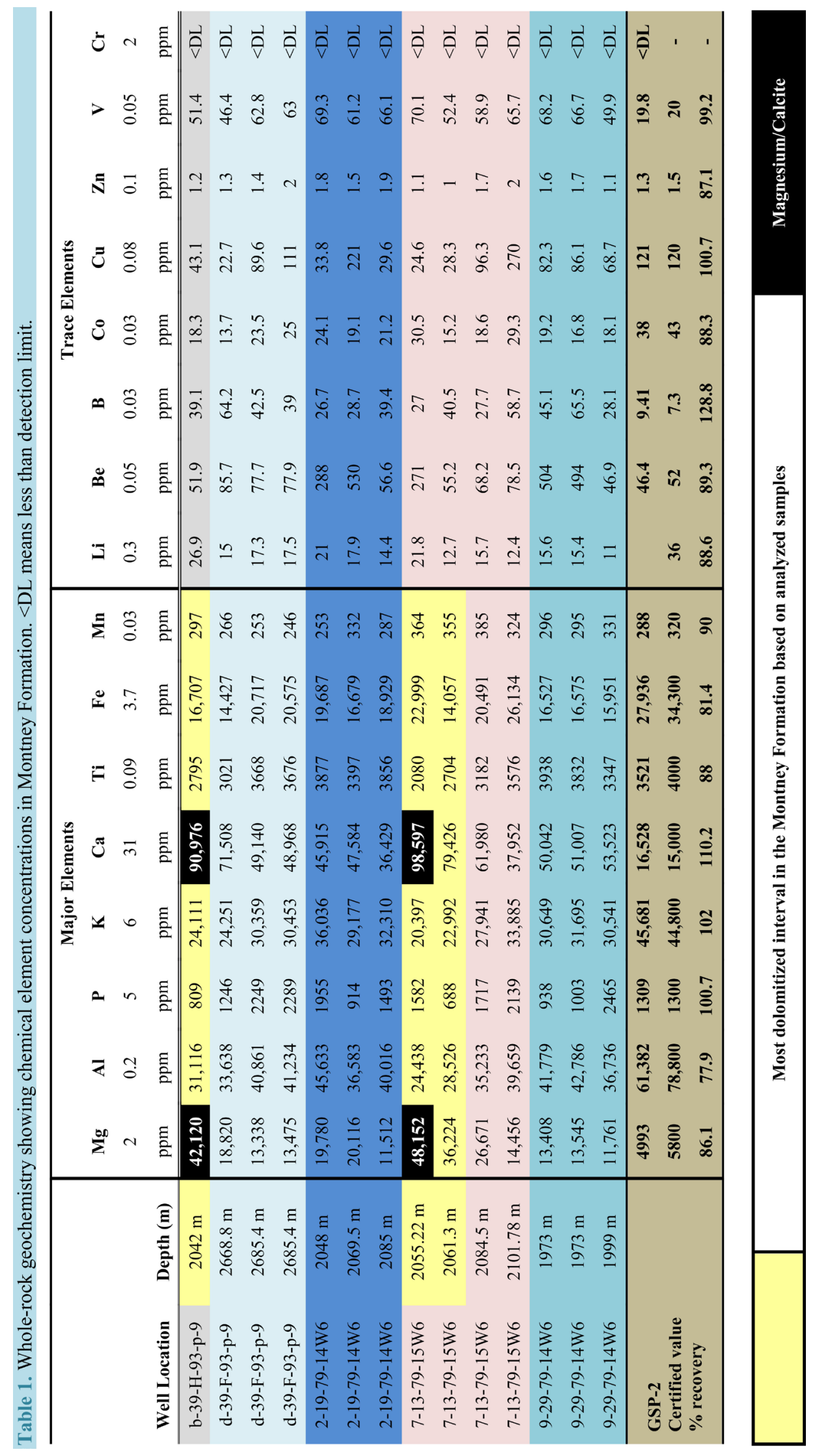




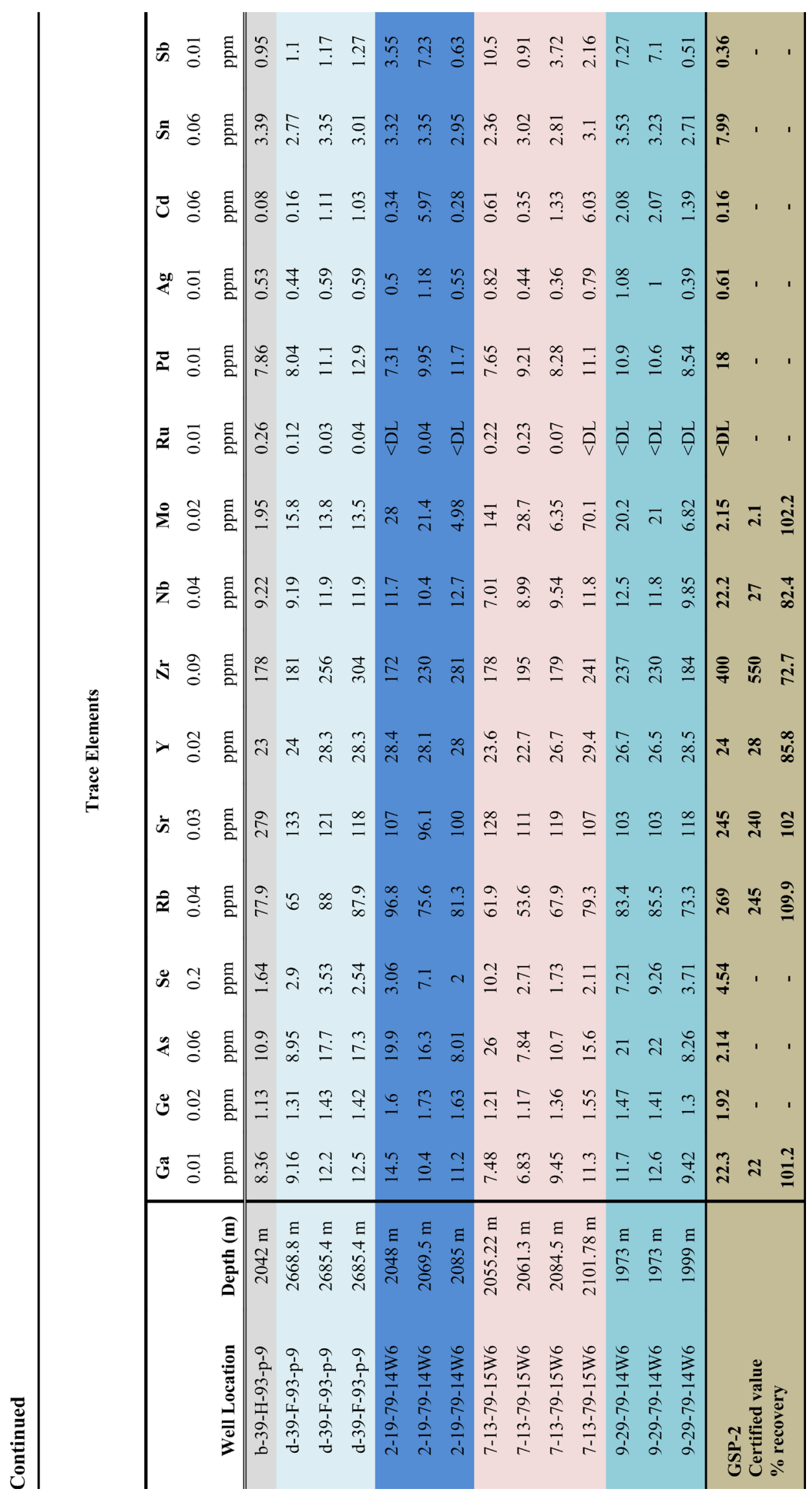




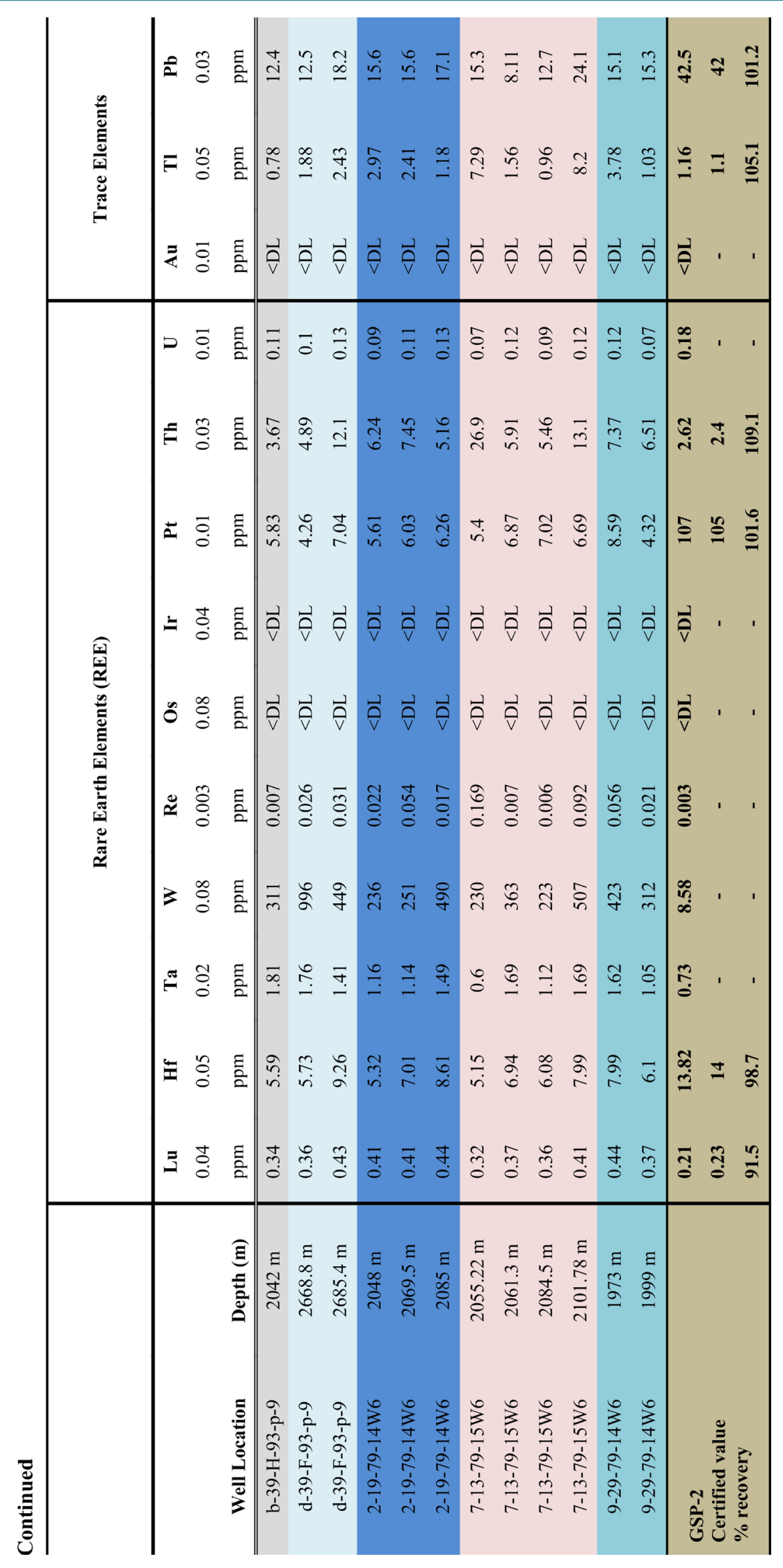




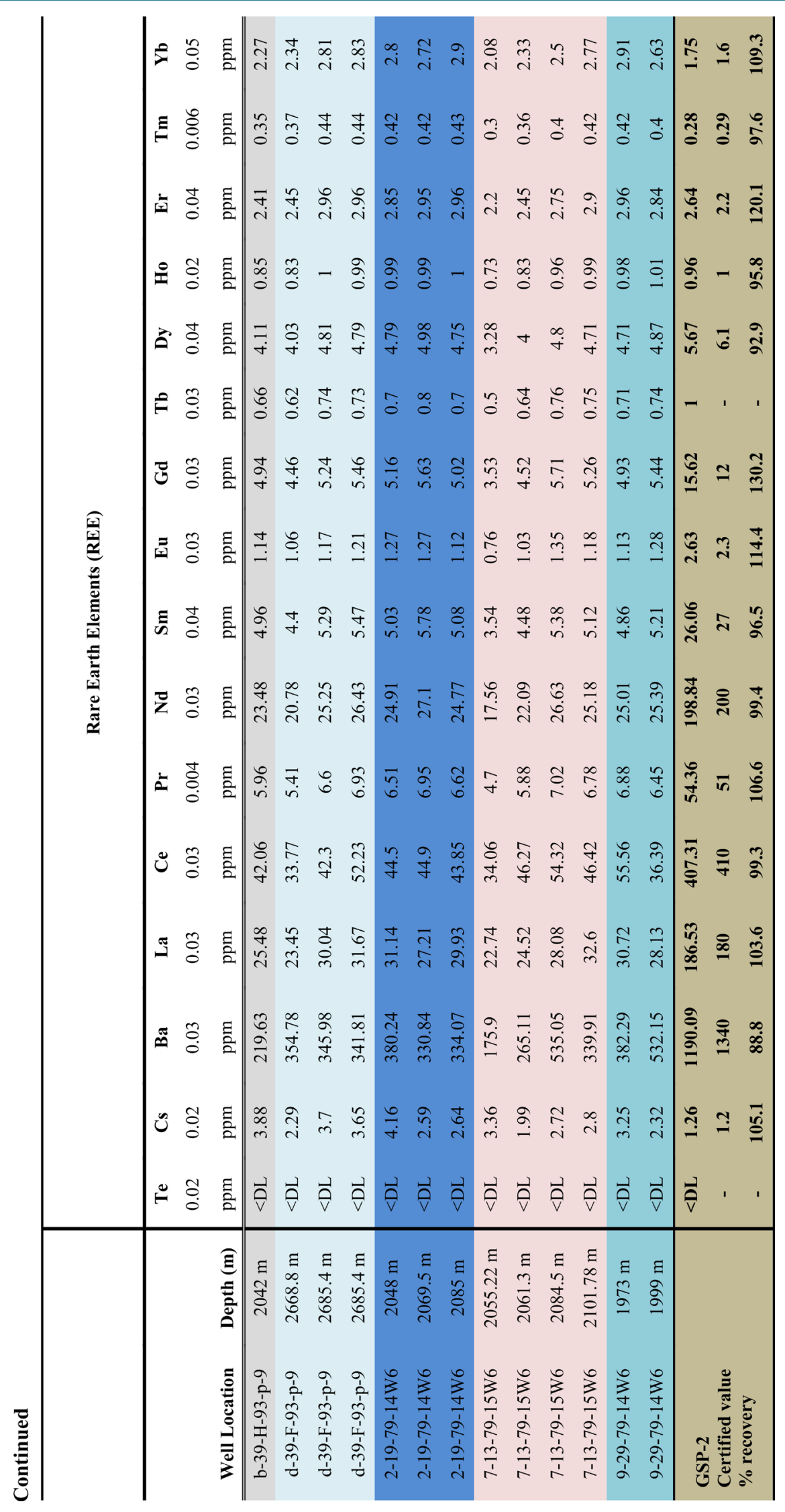


Table 2. Quantitative X-ray diffraction (XRD) analyses showing whole-rock mineralogy of the Montney formation, British Columbia, western Canada. Data source: B.C. Oil and gas commission.

\begin{tabular}{|c|c|c|c|c|c|c|c|c|c|c|c|}
\hline $\begin{array}{c}\text { Depth } \\
\text { (meters) }\end{array}$ & Formation & Quartz & K Feldspar & Plagioclase & Calcite & Dolomite & Pyrite & Marcasite & Apatite & Kerogen & $\begin{array}{l}\text { Total } \\
\text { Clay }\end{array}$ \\
\hline 2233.70 & Montney & 21.2 & 4.5 & 6 & 32.9 & 20.7 & 1.8 & 0 & 0 & 5.4 & 7.6 \\
\hline 2236.40 & Montney & 15.2 & 5.2 & 2.1 & 52.9 & 9.8 & 1.1 & 0 & 2.8 & 8.1 & 2.9 \\
\hline 2238.00 & Montney & 19.8 & 5.3 & 5 & 50 & 15.8 & 1.1 & 0 & 0 & 1.2 & 1.8 \\
\hline 2240.80 & Montney & 19 & 4.8 & 3.4 & 25 & 20.3 & 2.5 & 0 & 0 & 17.6 & 7.3 \\
\hline 2242.50 & Montney & 16.6 & 2.9 & 3.5 & 43.5 & 5.9 & 1.1 & 0 & 18.6 & 6.9 & 1 \\
\hline 2245.60 & Montney & 23 & 4.5 & 5.2 & 36.1 & 8.2 & 2 & 0 & 6.5 & 8.7 & 5.8 \\
\hline 2248.10 & Montney & 30.9 & 9.1 & 7.2 & 14.4 & 8.9 & 2.4 & 0 & 3.9 & 15.9 & 7.3 \\
\hline 2251.50 & Montney & 24.4 & 5.5 & 5.4 & 31.9 & 7.7 & 2.2 & 0 & 2 & 11.3 & 9.6 \\
\hline 2252.60 & Montney & 24 & 6.9 & 5.1 & 28.8 & 8.7 & 1.8 & 0.3 & 2.2 & 13.2 & 8.9 \\
\hline 2259.50 & Montney & 33.6 & 13 & 9 & 10.7 & 14.7 & 1.2 & 0.6 & 2.5 & 11.7 & 3.1 \\
\hline 2260.60 & Montney & 20.7 & 3.8 & 9.1 & 39.5 & 18.7 & 0.9 & 0 & 0 & 3.9 & 3.3 \\
\hline 2262.00 & Montney & 22.9 & 6.7 & 9.5 & 43 & 10 & 1.2 & 0.6 & 0 & 1.5 & 4.7 \\
\hline 2262.70 & Montney & 49 & 7.9 & 12.1 & 9.7 & 9.5 & 1.5 & 0.6 & 0 & 0 & 9.7 \\
\hline 2265.20 & Montney & 20.6 & 4.7 & 7.3 & 53.1 & 6.2 & 1.2 & 0.3 & 0 & 2.4 & 4.4 \\
\hline 2273.00 & Montney & 41.3 & 7.9 & 9.7 & 8.8 & 15.9 & 2 & 0.7 & 0.9 & 3.6 & 9.4 \\
\hline 2279.20 & Montney & 34.6 & 9 & 10.9 & 9.9 & 17.4 & 1.6 & 0.5 & 0 & 6.3 & 9.8 \\
\hline 2281.20 & Montney & 37.5 & 7.4 & 10.1 & 11.8 & 12.9 & 1.5 & 0.5 & 0 & 8.1 & 10.2 \\
\hline 2282.40 & Montney & 39.9 & 7.8 & 9.9 & 10.4 & 9.8 & 1.8 & 0.4 & 1 & 9.1 & 10 \\
\hline 2288.40 & Montney & 38.7 & 8.5 & 10.7 & 10.4 & 13.5 & 1.5 & 0.4 & 0 & 5.8 & 10.4 \\
\hline 2294.60 & Montney & 44.9 & 7.9 & 13.6 & 9 & 12.6 & 1.4 & 0.4 & 0 & 0.1 & 10.2 \\
\hline 2299.40 & Montney & 31.9 & 6.3 & 11.4 & 25.4 & 10.5 & 0.9 & 1 & 0 & 4.6 & 7.9 \\
\hline 2317.80 & Montney & 33.3 & 7.1 & 9.9 & 2.9 & 33.1 & 1.1 & 0.7 & 0 & 2.6 & 9.4 \\
\hline 2318.50 & Montney & 38.3 & 8.4 & 12.5 & 3 & 20.3 & 1.3 & 0.4 & 0 & 3.5 & 12.1 \\
\hline 2323.90 & Montney & 37.8 & 7.8 & 12.5 & 3.4 & 21.4 & 1.2 & 0.4 & 0 & 4.5 & 11 \\
\hline 2330.30 & Montney & 40.8 & 7.8 & 13.4 & 4.8 & 15.7 & 2.2 & 0.8 & 0 & 0.1 & 14.5 \\
\hline 2332.80 & Montney & 31 & 6.5 & 8.6 & 4.7 & 31.7 & 1.5 & 0 & 0 & 6.8 & 9.2 \\
\hline 2341.90 & Montney & 43.2 & 6.8 & 12.3 & 6.2 & 14.2 & 1.1 & 0.5 & 0 & 4.8 & 10.9 \\
\hline 2352.39 & Montney & 22.5 & 3.5 & 8 & 13.7 & 41.5 & 1 & 0 & 0 & 3.4 & 6.3 \\
\hline 2354.30 & Montney & 41 & 7.8 & 14.4 & 4.8 & 10.4 & 1.9 & 0.4 & 0 & 2.1 & 17.1 \\
\hline 2355.94 & Montney & 42.4 & 7 & 10.5 & 5.3 & 13.4 & 1.4 & 0.4 & 0 & 5.3 & 14.3 \\
\hline 2360.50 & Montney & 39.5 & 8.2 & 10.1 & 5.1 & 15.1 & 1.6 & 0.5 & 0 & 6.3 & 13.6 \\
\hline 2366.00 & Montney & 43.4 & 6.7 & 13 & 6.3 & 9.8 & 1.6 & 0.4 & 0 & 5.5 & 13.2 \\
\hline 2370.00 & Montney & 41 & 8.4 & 12.4 & 5.6 & 11.6 & 2.9 & 0.4 & 0 & 9.2 & 8.5 \\
\hline 2370.60 & Montney & 38.5 & 9.9 & 11.2 & 4.9 & 11.8 & 3.2 & 0.4 & 0 & 11.4 & 8.7 \\
\hline 2373.00 & Montney & 42.4 & 8.2 & 12.1 & 4.2 & 15.3 & 1.4 & 0.4 & 0 & 4.8 & 11.2 \\
\hline 2377.00 & Montney & 22 & 3.5 & 6.8 & 27.6 & 31.6 & 0.6 & 0.3 & 0 & 3.1 & 4.4 \\
\hline 2380.00 & Montney & 38.5 & 8.2 & 12.7 & 6.2 & 11.1 & 3 & 0.5 & 0 & 10.4 & 9.4 \\
\hline 2383.15 & Montney & 34.2 & 6.3 & 9.2 & 4.3 & 27.6 & 2 & 0.3 & 0.3 & 6.9 & 8.8 \\
\hline 2387.00 & Montney & 8.3 & 1.5 & 3.3 & 80.8 & 2.4 & 1.2 & 0 & 0 & 1 & 1.5 \\
\hline 2390.20 & Montney & 45.8 & 6.7 & 14.6 & 4.3 & 11.4 & 2.1 & 0.6 & 0 & 0 & 14.5 \\
\hline 2392.00 & Montney & 10.9 & 1.2 & 3.7 & 68.4 & 7.7 & 0.5 & 0.4 & 0 & 1.8 & 5.4 \\
\hline
\end{tabular}




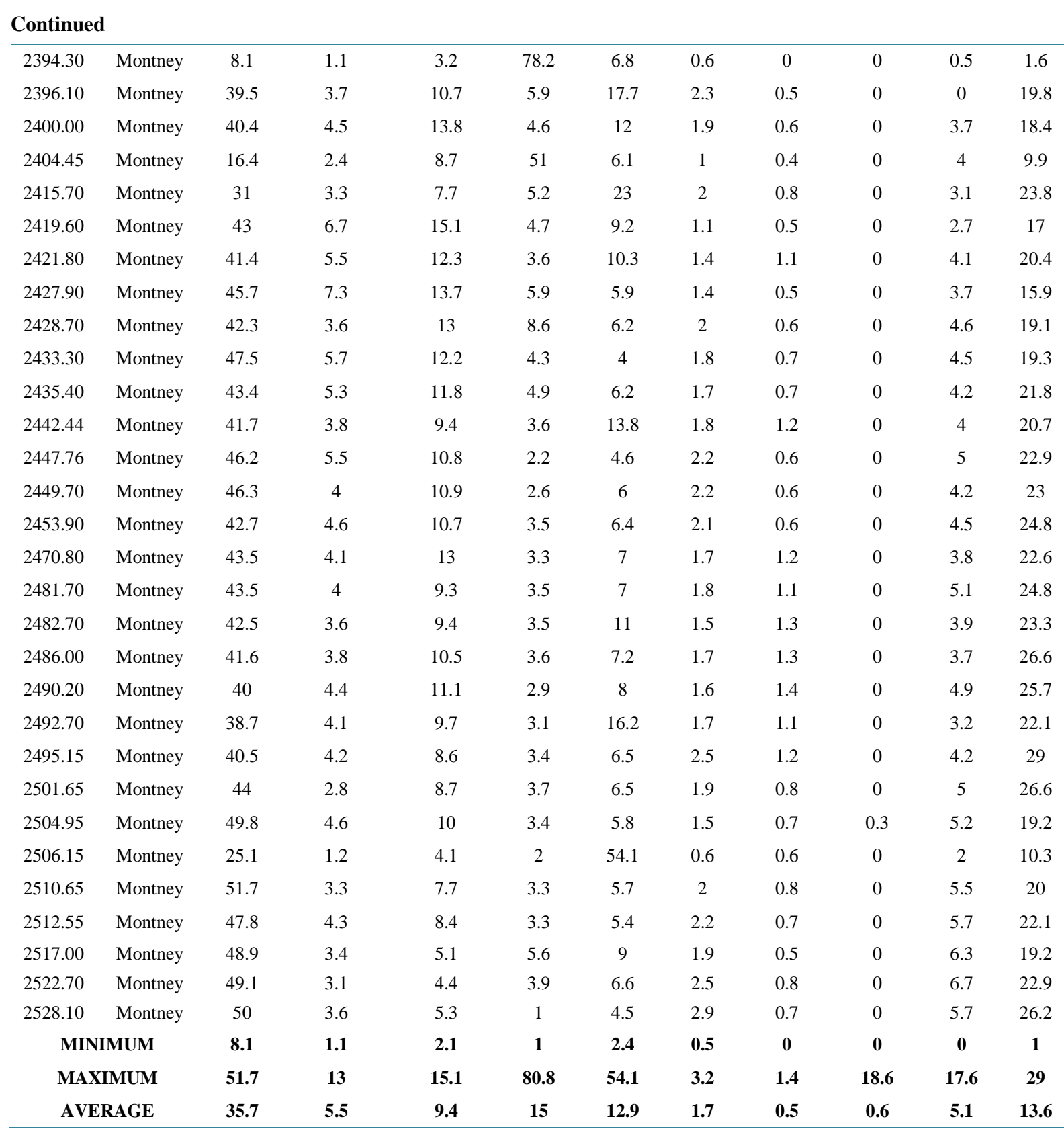

mation, scanning electron microscopy (SEM) and thin-section petrography shows diagenetic modification of Illite clay, and dissolution of organic matter replaced by pyrite (Figure 8 and Figure 9).

Mineralogy is key to characterization of the constituent composition of a rock, particularly, the present of magnesium and calcite are indication of dolomitization and diagenesis in the Montney Formation. Mica is a major component of siliciclastic sediments, and it is particularly more associated with silts and very fine-grained sediments [47]. Thin-section petrographic examination indicates that the dolomite in Montney Formation appears as detrital fragments (Figure 10)—suggesting that the dolomite may have been transported along with other materials, and may not have been formed in-situ. Similar detritus dolomite in siliciclastic have been reported by [49].

The Montney Formation mineralogy suggests that the sediments may have undergone advanced diagenetic alteration as evidenced by transformation of illite clay to polygorskite clay, dissolution of organic matter and replacement by pyrite (Figure 8(b)), authigenic quartz overgrowth and calcite cementation (Figure 11). X-ray 

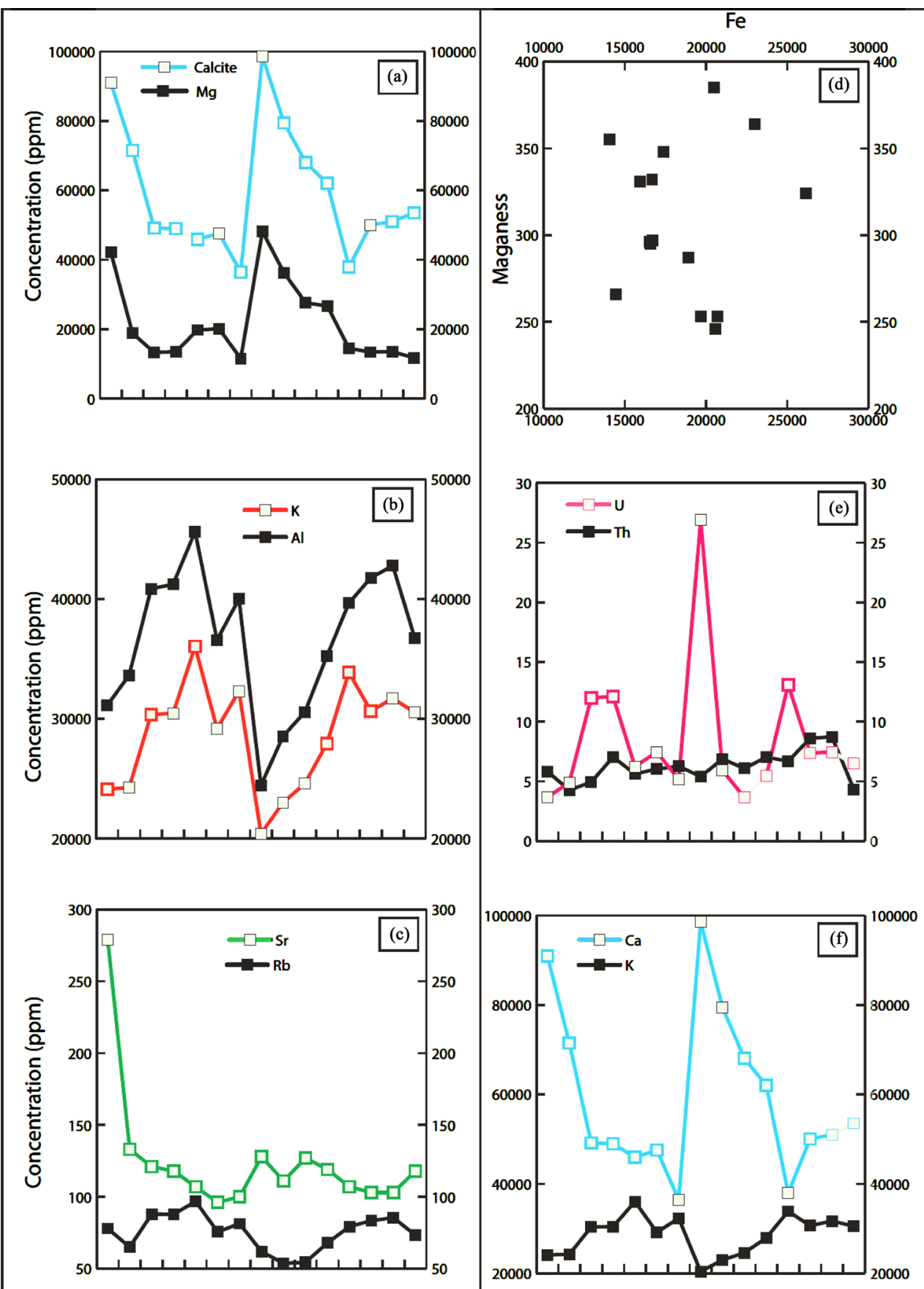

Figure 4. Shows the variation pattern of concentration of chemical elements. (a) Illustrates the composition of dolomite, in which there is higher concentration of magnesium $(\mathrm{Mg})$ relative to calcite $(\mathrm{Ca})$ component. The graph pattern shows good correlation between $\mathrm{Mg}$ and $\mathrm{Ca}$. (b) Shows major elements, potassium (K) and aluminum (Al). The concentration of $\mathrm{K}$ is very high because of the clay mineral and the organic matter richness of the Montney Formation sediments. The $\mathrm{Al}$ concentration is related to the clay mineralogy and partly has affinity to organic matter. (c) Shows alkaline earth metals-Strontium ( $\mathrm{Sr}$ ) and Rubidium (Rb) concentration. (d) Illustrates the concentration of Iron (Fe) and Manganese (Mn). High Fe content and $\mathrm{Mn}$ are both related to diagenesis. The concentration of Fe is very high compared to the concentration of Mn. This indicates that Fe has more dominating diagenetic influence in the Montney Formation. (e) Shows the relationship between radioactive elements-Uranium (U) and Thorium (Th). These elements are particularly related to the clay mineralogy and organic matter components of the Montney Formation sediments-source rock kerogen. (f) Shows the relationship between calcite (Ca) and Potassium (K). Evidently, Ca has enormously high concentration due to the stoichiometric co-existence with dolomite. 


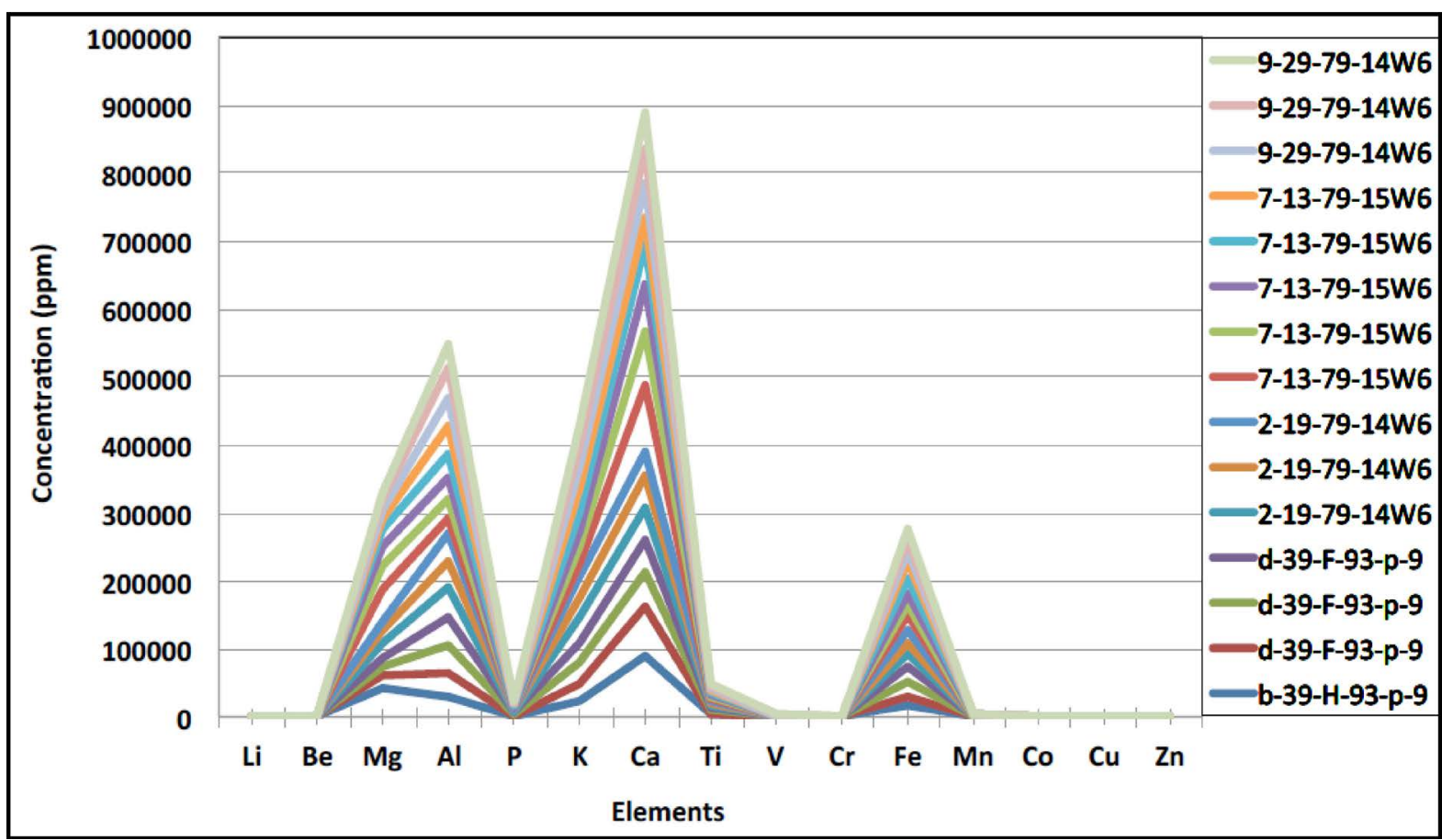

Figure 5. Element concentration showing distinct pattern that reflects the major elements compared to the trace elements with very low concentration.

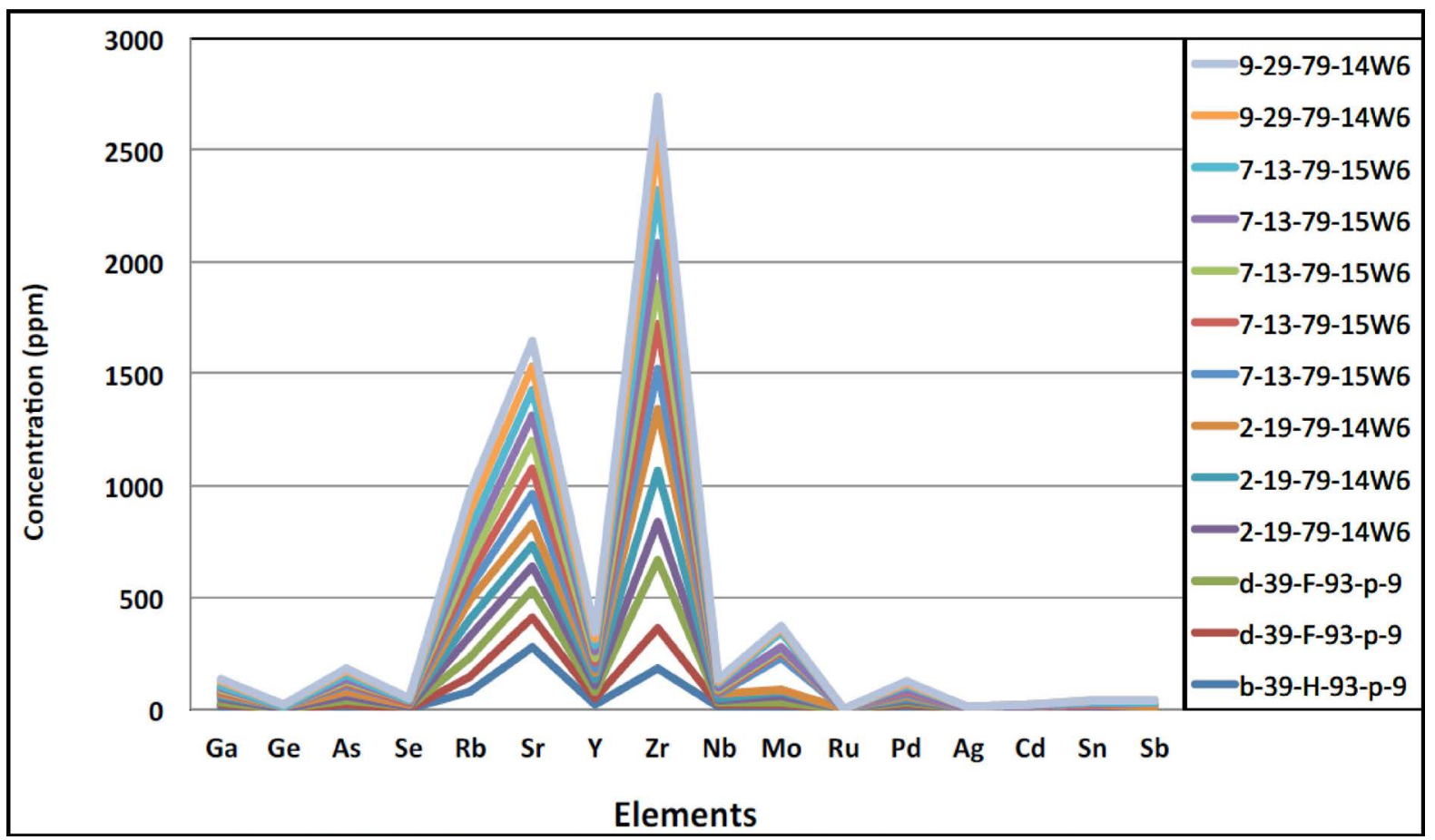

Figure 6. Trace element concentration indicates high values in Rubidium (Rb), Strontium (Sr), and Zirconium (Zr).

diffraction response of illite (clay mineral) is an indication of diagenesis and low-grade metamorphic history of a sedimentary rock [50]-[54]. Kaolinite is transformed to illite during the process of diagenesis, typically at temperatures of $212^{\circ} \mathrm{F}-230^{\circ} \mathrm{F}\left(100^{\circ} \mathrm{C}-110^{\circ} \mathrm{C}\right)$, which lies within the oil generating window [55], and thus confirms diagenesis in the Montney Formation. 


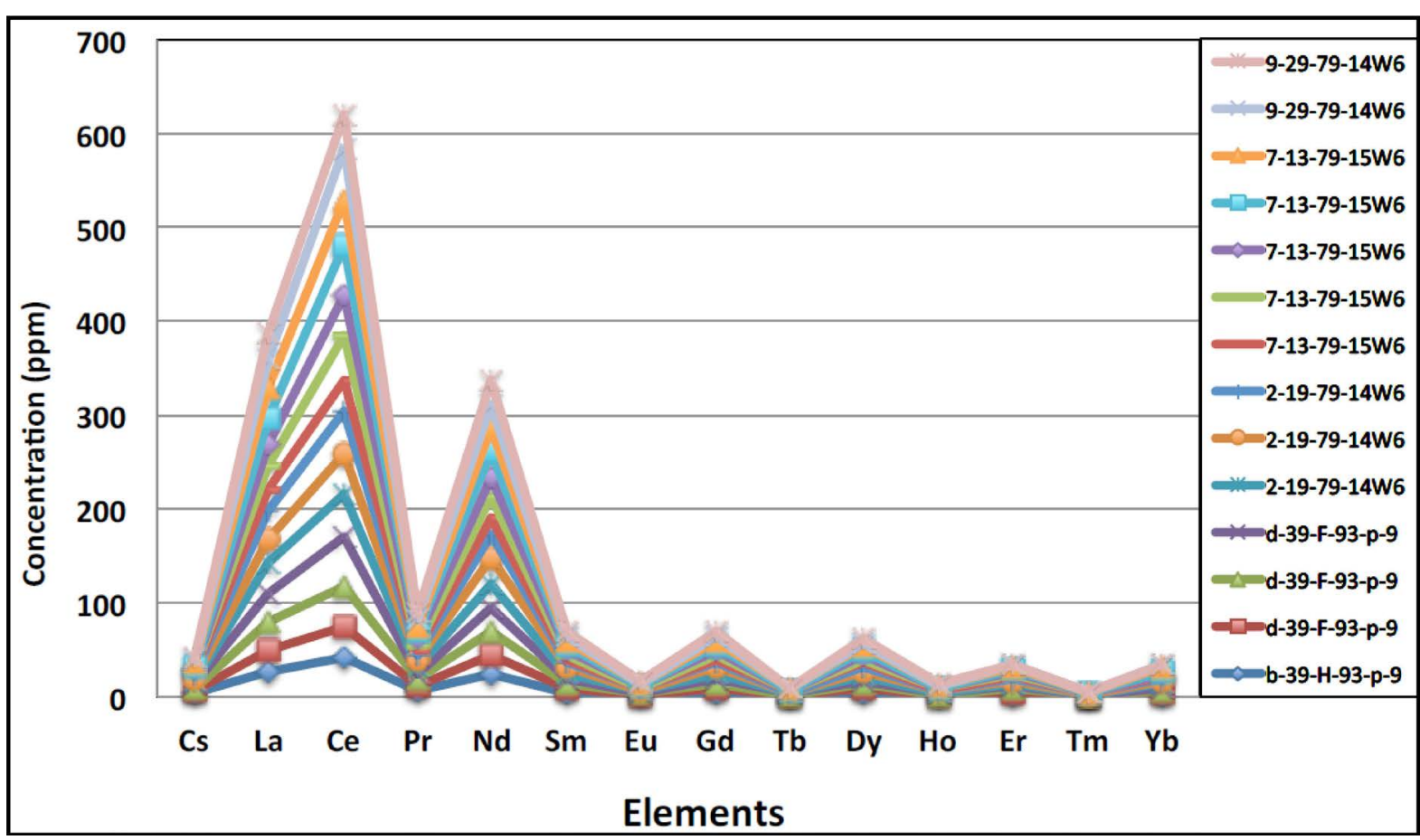

Figure 7. Illustrates the concentration of rare earth elements (REE). The pattern of the graph shows a systematic decrease in their concentration following the pattern in the periodic table with concentration decreasing.
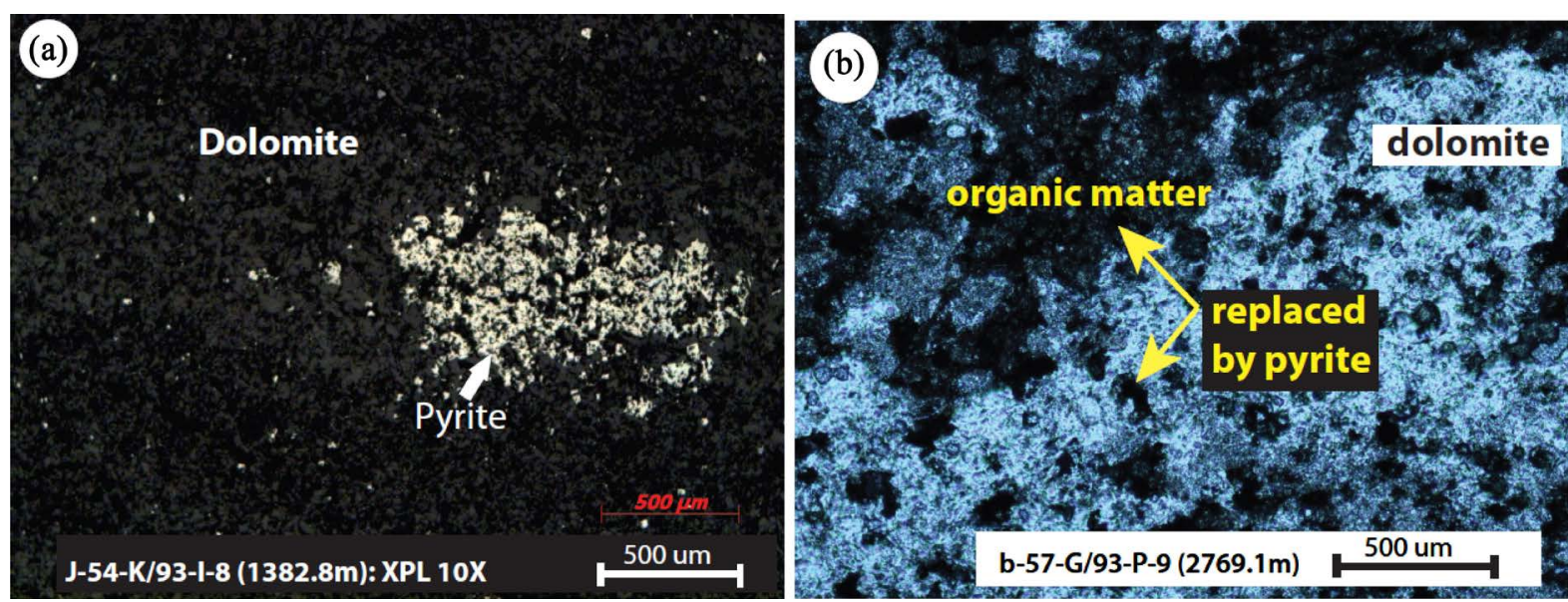

Figure 8. Microphotographs showing thin-section petrography of the Montney Formation illustrating mineralogical composition. (a) Dolomite and pyrite (b) Illustrates pyritized, dolomitized, organic matter rich siltstone. Pyrite replaces organic matter during decomposition of organic matter due to diagenesis.

Pyrite in the Montney Formation is related to post-depositional emplacement [56] caused by the dissolution of organic matter due to diagenesis (Figure 8). Pyrite is an important diagenetic mineral and its occurrence can help define the diagenetic history of sediments [57]. Hence, the occurrence of pyrite in the Montney Formation is a strong evidence of post depositional changes, and interpreted herein to have formed in-situ during diagenesis.

The clay mineral is associated with the organic carbon richness-kerogen component of the Montney Formation source rock. [58] study the relationship between organic matter and shale in modern sediments and found that adsorption of carbon compounds onto clay mineral surfaces played a fundamental role in the burial and preservation of total organic carbon in the sediment. This evidence proved that organic matter are within the smectite inter-layers of clay, which implies that hydrocarbon prone source rock may be closely related to clay 


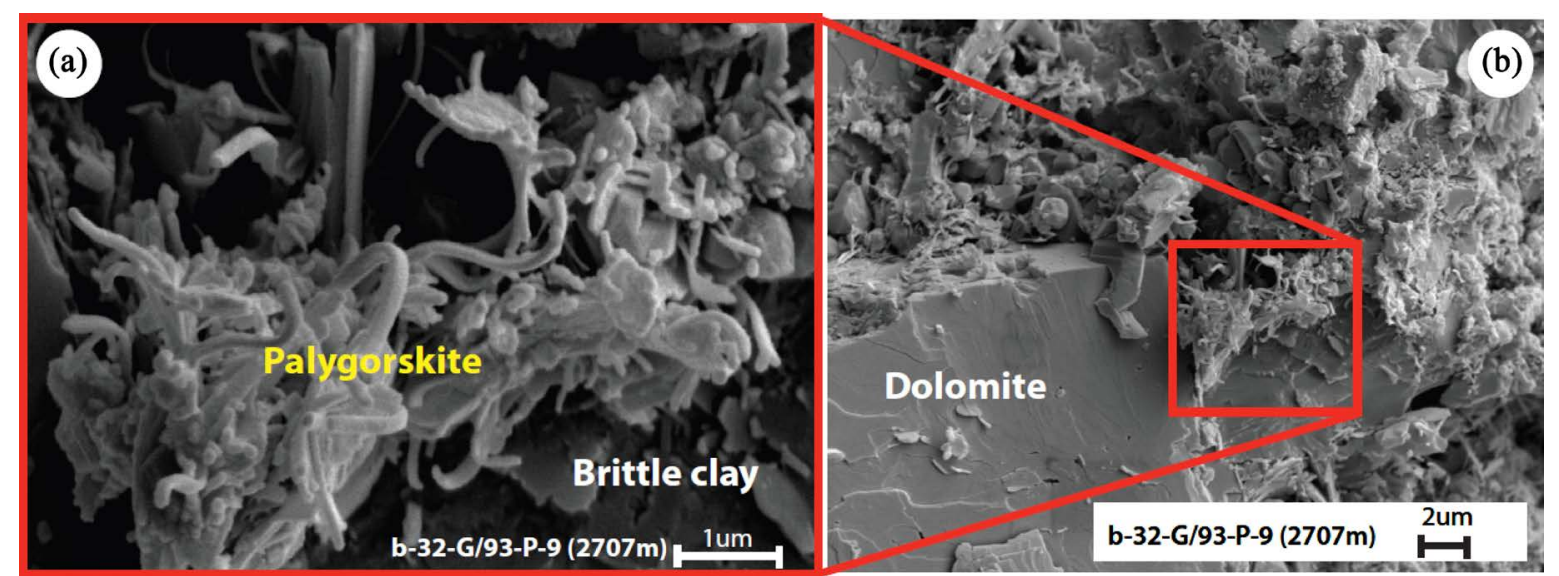

Figure 9. SEM images showing mineralogy of the Montney Formation. (a) Illustrates a very well formed palygorskite clay - a form of clay mineral growth, formed from the transformation of dickite to Illite, and further transformation of Illite to palygorskite due to severe temperature and pressure in a diagenetic regime. (b) Dolomite and clay mineral.
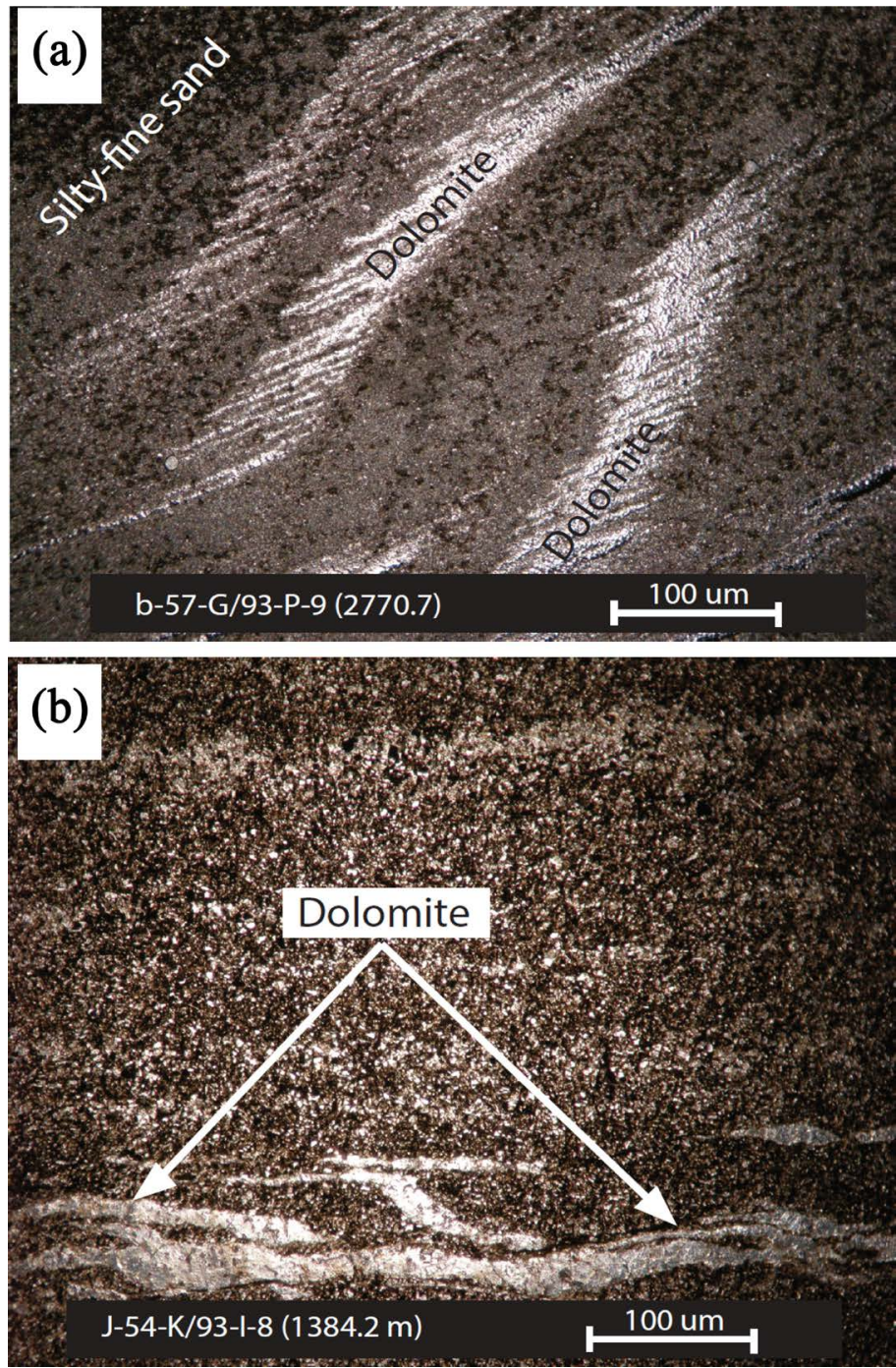

Figure 10. Photomicrographs showing dolomitic silty-sandstone. (a) Shows detrital dolomite resembles ripple. (b) shows detrital dolomite admixed siltstone. 
mineralogy [58]. The depositional mechanism of silt-sized grains and clay mineral may be related to flocculation of fines due to the affinity of mica mineral as a major component of siliciclastic sediments, which are particularly more associated with silts and very fine-grained sediments [47].

[59] observed that the distance of transport of clay rich sediments affects clay mineral composition, thus they differ from one depositional environment to another (e.g., coastal clay mineral differs from continental slope clay mineral). The observation of [59] shows that chlorite proportion of clay mineral increase from the lower slope to upper slope, corresponding with a decrease in the proportion of smectite. The illite component of the clay generally reaches its maximum on the middle slope [59]. Differential proportion of clay in the different depositional environment may be due to different mineral grain-sizes that characterize different depositional settings, and the different affinities to flocculation effects associated with deposition of hemipelagic [59]. The illitic/palygorskite in the Montney Formation has significant interpretation in relation to petrogenesis. [60] stated that kaolinite tends to flocculate near the river mouths, whereas illite and montmorillonite (smectite) are transported further offshore, thus, supporting a distal depositional environment interpretation for the Montney Formation. [61]-[63] have reported similar depositional environment based on clay mineralogy.

\subsection{Chemical Elements Geochemistry}

The major elements, trace elements and Rare Earth Element—REE (Lanthanide) detected in the analyzed samples of the Montney Formation are interpreted based on their concentration, natural abundances in Earth's crust, mode of formation, and affinity with mineralogy. The Montney Formation whole-rock mineralogy (Table 2) as determined by XRD analyses shows average dominance of the minerals: quartz (36.3\%), dolomite (15.5\%), pyrite (14.1\%), calcite (9.4\%), K-feldspar (5.6\%), marcasite (3.3\%), apatite (1.0\%), clay (0.7). The abundance by volume of clay minerals (maximum value obtained) indicates that clay is $29 \%$ (Table 2).

Detrital minerals such as quartz, feldspar, and clays are a result of the host rock. The Montney Formation host rock is mainly siltstone/mudstone characterized by high concentrations of $\mathrm{SiO}_{2}, \mathrm{CaMg}\left(\mathrm{CO}_{3}\right)_{2}, \mathrm{Al}_{2} \mathrm{O}_{3}, \mathrm{KALSi}_{3} \mathrm{O}_{8}$, $\mathrm{NaAlSi}_{3} \mathrm{O}_{8}, \mathrm{CaCO}_{3}, \mathrm{Fe}_{2} \mathrm{~S}_{2}, \mathrm{TiO}_{2}, \mathrm{~K}_{2} \mathrm{O}$ and $\mathrm{Na}_{2} \mathrm{O}$ as shown in XRD mineral spectrum. Manganese (Mn) is highly insoluble in oxic environment and is buried as oxyhydroxide particles and coatings of the sediment is mobilized either by reduction of manganese oxyhydroxides [64], or as a result of solubility equilibria, in which $\mathrm{Mn}^{+2}$ then diffuses along a pore-water concentration gradient from anoxic conditions and immobilized by the oxidation of $\mathrm{Mn}^{+2}$ resulting in the precipitation of manganese oxyhydroxides [65]-[67]. This process can produce near surface diagenetic manganese contents [68]-[70]. Thus, the present of $\mathrm{Mn}^{+2}$ in the Montney Formation indicates association with organic matter in anoxic condition, and the diagenesis associated with the transformation of kerogen during the thermal maturation phase of source rock.

The relatively high amounts of uranium (U), potassium (K), arsenic (As) and barium (Ba) detected in the samples are related to the Montney Formation organic matter richness and high phosphate content in the upper Montney/Doig Formation boundary. These elements (U, K, AS, Ba) are mainly associated with organic matter due to several depositional factors in phosphatic rocks, and are comparable to those detected in other phosphate worldwide [71]. This explains the phosphatic and diagenetic phenomenon in the Upper Montney/Doig formations boundary as evident by the present of apatite mineral in the Montney Formation.

The trace element Gallium (Ga) has chemical affinity with Aluminum (Al) thus its enrichment is attributed to the presence of alluminosilicate minerals [72]. Aluminum make up about $8 \%$ of the Earth's solid surface, and it is the third most abundant element in the Earth's crust, second only to oxygen and silicon [73]. The formation of aluminum has been attributed to several mechanisms associated with reducing conditions, and aluminum is usually combined with other elements such as oxygen, silicon or fluorine to form different compounds [73]. Native metals like aluminum can form in reducing oceanic or mud volcanic environments, which are associated with upward migration of basaltic magma [74], hydrothermal activity [75], magmatic or metamorphic process [76], or high temperature hydrocarbon-enriched fluids [77]. However, aluminum can also be formed by exolution of metal-rich fluids in the magma [78] and degassing of magmatic vapors during submarine eruptions, which may lead to reduction of some elements in their metallic state [79]. Other mechanisms for aluminum formation includes: 1) gas condensate from metalliferous fluids together with fairly other dry reducing gasses [74] [75] [80]; 2) reduction of carbon compounds [81]; 3) reduction by intratelluric fluids and reaction of aluminum chloride $\left(\mathrm{AlCl}_{3}\right)$ with $\mathrm{H}_{2}$ [91]). Aluminum has affinity to clays, and because clay mineral is a component of the Montney Formation, thus, the high content of aluminum in the samples analyzed. 
Lithium ( $\mathrm{Li}$ ) concentration is attributed to the presence of mica minerals, whereas, Nickel (Ni), Copper (Cu), Chromium (Cr), and Vanadium (V) enrichments can be attributed to the presence of minerals related to maficultramafic rocks such as vermiculite and chlorite [82] [72]. Copper $(\mathrm{Cu})$ is critical to the behavior of the elements associated with biological processes in the sedimentary cycle [83]. Copper $(\mathrm{Cu})$ is associated with clay mineral fractions, especially those rich in coatings containing organic carbon and manganese oxides [2].

The high amounts of Zirconium ( $\mathrm{Zr}$ ) are related to Hafnium (Hf), and are in general fixed in silicate minerals [72]. Rubidium $(\mathrm{Rb})$ is most likely related to the potassium feldspars contained in the clay component of the Montney Formation. Enrichments in elements such as Barium (Ba), Lead ( $\mathrm{Pb})$, Yttrium (Y) was reported by [82] as evidence of diagenetic alterations of the sediments from lagoonal environment. Thus, their presence in the Montney Formation is interpreted as evidence of diagenesis. The element Barium (Ba) is related to biogenic compounds, it is suggested that Barium in the form of Barite was adsorbed by planktonic organisms from seawater and sunk down to the bottom of the sea [71]. The present of Barium (Ba) is associated with the high organic matter richness of the Montney Formation. Barium (Ba) typically migrates and is redeposited along with phosphates [84]. The Montney and Doig formations boundary have very high phosphate concentration, which contributes organic carbon content.

Iron $(\mathrm{Fe})$ hydroxides seem to be the main sinks for Lead $(\mathrm{Pb})$, Cadmium (Cd), and Zinc ( $\mathrm{Zn})$, with less important role by organic matter [85]. Cadmium (Cd) is generally found where there is high concentration of organic matter such as muddy deposit associated with benthic layers [86]. Iron (Fe) and Aluminum (Al) contents provide useful information on the clay, contamination and sedimentation style [87]. Most Iron (Fe) is structurally bound by clay minerals. Fe is also an indication of diagenesis [56].

Boron abundance in carbonates provides a powerful proxy for seawater $\mathrm{pH}$ reconstruction [87]. The Boron (B) system in oceanic carbonates is a geochemical tool for paleo-seawater acidity reconstruction and indication of diagenesis [88] [89]. The relatively high concentration of Boron (B) in the Montney Formation sediments implies diagenesis. The work of [90] [91]; and [92] link main sources of oceanic Boron to riverine discharge and ridge hydrothermal fluid expulsion from accretion prisms. The main Boron sinks in the ocean are oceanic crust alteration, adsorption on sediments and co-precipitation in carbonates [90] [93] [94].

The diagenetic behavior of phosphorus $(\mathrm{P})$ in marine sediments is not well documented [64]. However, phosphate is produced during oxidation of organic matter in the sediment by the dissolution of inorganic particulate phosphates, and by the liberation of phosphate associated with iron oxyhydroxides following their reduction to $\mathrm{Fe}^{+}$. [64] stated that it is inferred that phosphate is precipitated in the sediment by unspecified inorganic diagenetic process. Phosphorous does preferentially remain in solution in reducing conditions because under oxic conditions it is bound to iron [95]. Therefore, the behavior of phosphorous can be related to the dissolution and precipitation of iron compounds in response to redox-driven processes [64].

The behaviors of cobalt $(\mathrm{Co})$, copper $(\mathrm{Cu})$ and nickel $(\mathrm{Ni})$ are closely related to manganese during diagenesis [66] [96] [97] [99]. Pore-water data from hemipelagic sediments indicate that both cobalt and nickel reach dissolved maxima in manganese-reduction zone and are precipitated along with manganese-oxidation zone [100].

Cobalt and nickel are progressively depleted in pore-waters of the iron-reduction zone, indicating uptake by the sediment under reducing condition [64]. Pore-water from pelagic and hemipelagic sediments indicate that copper is mobilized from labile solid phases, which is predominantly related to organic matter decomposition during diagenesis [97]-[99]), and reaches a dissolved maximum immediately below the sediment-water interface [64]. In addition, copper is mobilized in the manganese-reduction zone, where it is co-precipitated with manganese in sediments [97]. Trace elements such as La, Ce, Nd, Y, Th, Zr, Hf, Nb, Ti and Sc are mostly used for interpreting provenance and tectonic setting because of their relatively low mobility during sedimentary processes, and their low residence time in seawater [1] [101]. These elements are transported quantitatively into clastic sedimentary rocks during transport of weathered materials, and thus reflect the signature of the parent-source rock [101]. The present of La, Ce, Nd, Y, Th, Zr, Hf, Nb, Ti and Sc elements in the Montney Formation may infer somewhat tectonic stability. Similar interpretation based on the present of La, Ce, Nd, Y, Th, Zr, Hf, Nb, Ti and Sc was documented by [101].

\section{Discussions}

Ever since Dolomieu [102] first introduced the term 'Dolomite' into the geological literature to describe a calcareous rock in the mountain range of northwestern Italy where the rock 'dolomite' was first identified, the cal- 
cium magnesium carbonate $\mathrm{CaMg}\left(\mathrm{CO}_{3}\right)_{2}$ rock continue to be a subject of vast interest in geology owing to: 1) mode of formation of the mineral dolomite; 2) diagenesis, and implications of dolomitization in reservoir rocks; and 3) its usefulness as paleotemperature indicator, or as paleothermometer.

Dolomite is a rhombohedral carbonate with the ideal formula $\mathrm{CaMg}\left(\mathrm{CO}_{3}\right)_{2}$, in which calcium and magnesium occupy preferred sites [103] [104]; [105] used hydrothermal experiments extrapolated to low temperatures to demonstrate that calcite and dolomite are essentially ideal in composition at $25^{\circ} \mathrm{C}$. Thus, any double carbonate crystal of $\mathrm{Ca}$ and $\mathrm{Mg}$ at $25^{\circ} \mathrm{C}$ is not essentially pure dolomite, and is either metastable or unstable with respect to calcite [103]. Diagenetic modification of the very fine-grained, silty-sandstone of the Montney Formation may have occurred in stages of progressive oxidation and reduction reactions involving chemical element such as Fe, which manifest in mineral form as pyrite (Figure 8), particularly, during early burial diagenesis, or late stage diagenesis. Similar interpretation was documented by [106]. Mineralogical changes in the form of cementation and mineral replacement involving calcite and dolomite are typical of diagenesis [107], and are evident in the Montney Formation based on petrographic study and SEM analysis.

Oxidation and reduction reaction mechanisms are crucial in the modification of sediments, shortly after burial, prior to lithification or compaction during which fluids are ejected into the depositional interface [108] [109]. This drives the oxidation and reduction processes involving Fe, sulfur, and carbon [107]. The significant amounts of organic matter (TOC) in the Montney Formation essentially make these elements principal reactants. The carbon compound of the organic matter content is the most rapidly oxidized and consequently contributing energy to drive the Fe into the ferrous state, thereby causing fixation of sulfur as pyrite. Because of the present of organic matter in the Montney sediments, pyrite occurs as scattered "clots" throughout the rock samples-this phenomenon is evident in thin-section petrography (Figure 8). Pyrite is related to post-depositional emplacement [56] caused by the dissolution of organic matter due to diagenesis (Figure 8).

The quantitative analysis of mineralogy (Table 2), chemical elements and their concentration (Table 1) in the Montney Formation, particularly, Ca and Mg show incredibly high concentration owing to mineral precipitation and dolomitization. It is interpreted thus, that calcite may have been precipitated into the interstitial pore space of the intergranular matrix of the very fine-grained silty-sandstone of the Montney Formation as cement by a complex mechanism resulting in the interlocking of grains, welded together by calcite cement. Evidence of grain interlocking is revealed by SEM image showing authigenic quartz overgrowth (Figure 11). It is established through mineralogical composition in this study (Table 2) that the Montney Formation is quartz rich and contains substantial clay minerals as well, including unstable mineral such as feldspar (Table 2). This sort of compositional mixture of quartz, clay and feldspar minerals may have resulted in the decomposition of feldspar along the clay-quartz boundary due to processes involving hydrolysis in the process of diagenesis.

The depositional environment interpreted for the Montney Formation is proximal to distal offshore marine setting [35] [19] [20]. In the marine environment, several weathering and transformation are prevalent. As a result, there exist an exchange of cations, in which the positions of clay minerals are changed, thereby resulting in the substitution of $\mathrm{Mg}$ for Ca [103] [105] [110]. In the marine environment, chlorite and illite minerals are formed by fixation of $\mathrm{Mg}$ and $\mathrm{K}$ in montmorillonite or degraded illite delivered into distal offshore settings due to continental denudation resulting from fluvial processes [110].

The present of illite and palygorskite clay mineral (Figure 9) support the evidence of diagenesis in the Montney Formation formed from ionic solutions in extreme conditions of temperature and pressure. [50] noted that the transformation of clay minerals into illite involves several factors such as preferential flocculation, current sorting of floods (hyperpycnal or hypopycal) intensities, and variations in the composition and concentration of detritus during sedimentation and subsequently enhance clay transformation.

The dolomite in the Montney Formation appears as debris in thin-section petrography (Figure 10). Such allogenic (non in-situ) dolomite may have only played a role (minimal) in the Montney Formation diagenesis, compared to sediments that are mainly composed of biogenic carbonate that are formed completely from aragonite and calcite. Thus, authigenic calcite may have played dominant role in the vast diagenetic phenomenon of the Triassic Montney Formation in northeastern British Columbia based on the evidence of the most dolomitized interval, which have the highest percentage of calcite composition (Table 1)—shaded in black color.

\section{Conclusions}

Whole-rock chemical element geochemistry provides a means of understanding the chemical, physical, and geological forces that continually redistributes elements between living and non-living reservoirs through bio- 


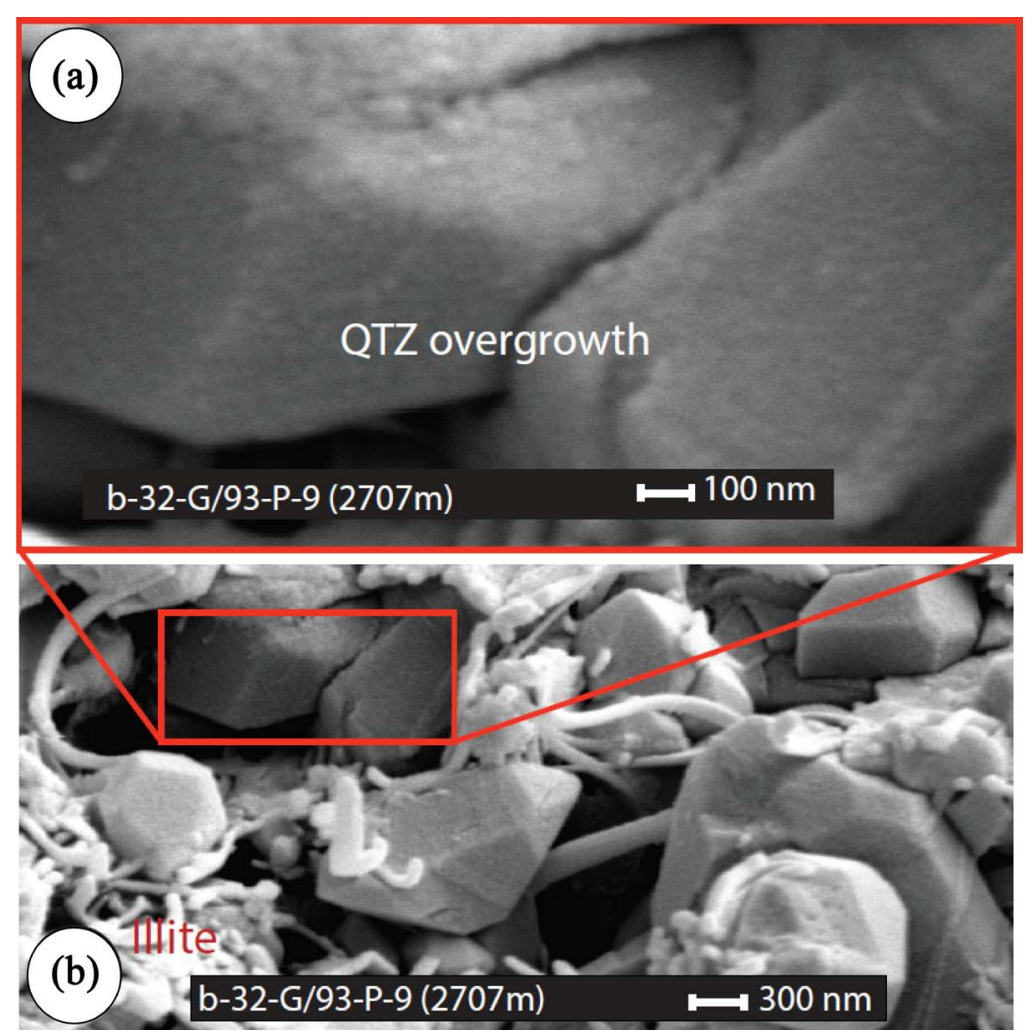

Figure 11. SEM images shows evidence of diagenesis. (a) Insect of Plate B showing authigenic quartz overgrowth due to diagenesis. (b) Shows quartz overgrowth (red rectangle), illite clay and quartz mineral.

geochemical cycles [4]. The understanding of the variability and affinity of chemical elements and mineralogy in rocks are invaluable, which aid identification and interpretation of chemical elements and mineralogical signatures, thereby serving as a means of quantification, calibration, and correlation in sedimentary basins.

Results from this study show that chemical elements such as major, trace and rare earth element (REE) concentrations in the Triassic Montney Formation sediments (very fine-grained, dolomitized silty-sandstone) are related to the host rock mineralogy. The variation patterns of some of the major elements ( $\mathrm{Al}, \mathrm{Fe}, \mathrm{K}, \mathrm{Mg}$ and $\mathrm{Mn}$ ) and trace elements (Sc, V, Co, Cr, Zn, Ba, Th, U, Rb and Cs), show strong affinity to the host rock mineralogy. This evidence is supported by quantitative XRD mineralogical analyses (Table 2). Mineralogy is key to characterization of the constituent composition of a rock, hence, mineralogical analysis from this study helped to understand dolomitization and diagenesis of the Montney Formation in northeastern British Columbia, Western Canada Sedimentary Basin (WCSB).

\section{Acknowledgements}

B.C. Oil and Gas Commission is thanked for providing the Montney Formation well data, lab reports, and for granting the authorization to use the data for publication in a Journal. Special thanks is accorded to Hardy Friedrich, Manager of Communications at the B.C. Oil and Gas Commission, who communicated the authorization to use the data for publication. Darcie Wetland with "Wells-Files" department at B.C. Oil and Gas Commission is thanked for the timely provision of the data and numerous support during data retrieval. The Geoscience B.C is thanked for providing funding for this research. Thanks to GuangCheng Chen for using the ICP-MS machine at the University of Alberta to determine chemical elements in the samples used in this study. Dee-Ann Rollings is thanked for her assistance with SEM image acquisition. The University of Alberta Faculty of Graduate Studies and Research is thanked for providing conducive academic and research environment that enhanced the success of this work. Professors Murray Gingras and J-P Zonneveld are thanked for providing the financial resource for field work and lab analyses. The Editor is thanked for the recommendation that greatly improved the quality of this paper. 


\section{References}

[1] Bowen, H.J.M. (1966) Trace Elements in Biochemistry. Academic Press, London, 241 p.

[2] Callender, E. (2004) Heavy Metals in the Environment-Historical Trends. In: Lollar, B.S., Ed., Treatise on Geochemistry, Environmental Geochemistry, US Geological Survey, Westerly, 68-105.

[3] Cooper, H.K., Duke, M.J.M., Simonetti, A. and Chen, G.C. (2007) Trace Element and Pb Isotope Provenance Analyses of Native Copper in Northwestern North America: Results of a Recent Pilot Study Using INAA, ICP-MS, and LA-MC-ICP-MS. Journal of Archaeological Science, 35, 1732-1747. http://dx.doi.org/10.1016/j.jas.2007.11.012

[4] Summons, R.E. (1993) Biogeochemical Cycles: A Review of fundamental Aspects of Organic Matter Formation, Preservation, and Composition. In: Engel, M.H. and Macko, S.A., Eds., Organic Geochemistry, Plenum Press, New York, 3-21. http://dx.doi.org/10.1007/978-1-4615-2890-6_1

[5] Bhatia, M.R. and Crook, K.A.W. (1986) Trace Element Characteristics of Graywackes and Tectonic Setting Discrimination of Sedimentary Basins. Contributions to Mineralogy and Petrology, 92, 181-193. http://dx.doi.org/10.1007/BF00375292

[6] Kasemann, S.A., Schmidt, D.N., Bijmaand, J. and Foster, G.L. (2008) In Situ Boron Isotope Analysis in Marine Carbonates and Its Application for Foraminifera and Palaeo-pH. Chemical Geology, 260, 138-147. http://dx.doi.org/10.1016/j.chemgeo.2008.12.015

[7] Leinen, M. and Pisias, N. (1984) An Objective Technique for Determining End-Member Compositions and for Partitioning Sediments According to Their Sources. Geochimica et Cosmochimica Acta, 48, 47-62. http://dx.doi.org/10.1016/0016-7037(84)90348-X

[8] Dymond, J., Suess, E. and Lyle, M. (1992) Barium in Deep-Sea Sediment: A Geochemical Proxy for Paleoproductivity. Paleoceanography, 7, 163-181. http://dx.doi.org/10.1029/92PA00181

[9] Murray, R.W. and Leinen, M. (1993) Chemical Transport to the Seafloor of the Equatorial Pacific across a Latitudinal Transect at $135 \mathrm{~W}$; Tracking Sedimentary Major, Trace, and Rare Earth Element Fluxes at the Equator and the ITCZ. Geochimica et Cosmochimica Acta, 57, 4141-4163. http://dx.doi.org/10.1016/0016-7037(93)90312-K

[10] Nesbitt, H.W. and Young, G.M. (1982) Early Proterozoic Climate and Plate Motions Inferred from Major Element Chemistry of Lutites. Nature, 299, 715-717. http://dx.doi.org/10.1038/299715a0

[11] Kronberg, B.I., Nesbitt, H.W. and Lam, W.W. (1986) Upper Pleistocene Amazon Deep-Sea Fan Muds Reflect Intense Chemical Weathering of Their Mountainous Source Lands. Chemical Geology, 54, 283-294. http://dx.doi.org/10.1016/0009-2541(86)90143-9

[12] Edwards, D.E., Barclay, J.E., Gibson, D.W., Kvill, G.E. and Halton, E. (1994) Triassic Strata of the Western Canada Sedimentary Basin. In: Mossop, G.D. and Shetson, I., Eds., Geological Atlas of the Western Canada Sedimentary Basin, Canadian Society of Petroleum Geologists, 257-275.

[13] Podruski, J.A., Barclay, J.E., Hamblin, A.P., Lee, P.J., Osadetz, K.G., Procter, R.M. and Taylor, G.C. (1988) Conventional Oil Resources of Western Canada. Geological Survey of Canada Paper, 149 p.

[14] Gibson, D.W. and Edwards, D.E. (1990) An Overview of Triassic Stratigraphy and Depositional Environments in the Rocky Mountain Foothills and Western Interior Plains, Peace River Arch Area. Bulletin of Canadian Petroleum Geology, 38A, 146-158.

[15] Zonneveld, J.P., MacNaughton, R.B., Utting, J., Beattty, T.W., Pemberton, S.G. and Henderson, C.M. (2010) Sedimentology and Ichnology of the Lower Triassic Montney Formation in the Pedigree-Ring/Border-Kahntah River Area, Northwestern Alberta and Northeastern British Columbia. Bulletin of Canadian Society of Petroleum Geology, 58, 115-140. http://dx.doi.org/10.2113/gscpgbull.58.2.115

[16] Davies, G.R., Moslow, T.F. and Sherwin, M.D. (1997) The Lower Triassic Montney Formation, West-Central Alberta. Bulletin of Canadian Petroleum Geology, 45, 474-505.

[17] Orchard, M.J. and Tozer, E.T. (1997) Triassic Conodont Biochronology, Its Calibration with the Ammonoid Standard, and a Biostratigraphic Summary for Western Canada Sedimentary Basin. Bulletin of Canadian Petroleum Geology, 45, 675-692p.

[18] Zonneveld, J.P., Gingras, M.K. and Pemberton, S.G. (2001) Trace Fossils Assemblages in a Middle Triassic Mixed siliciclastic-Carbonate Marginal Marine Depositional System, British Columbia. Palaeogeography, Palaeoclimatology, Palaeoecology, 166, 249-276. http://dx.doi.org/10.1016/S0031-0182(00)00212-1

[19] Egbobawaye, E.I., Kravchinsky, V.A., Zonneveld, J.-P. and Gingras, M.K. (2011) Magnetostratigraphy Dating and Correlation of the Lower Doig and Upper Montney Formations (Lower Triassic), Northeastern British Columbia, Western Canada. Canadian Society of Petroleum Geologists, CSPG, CSEG, CWLS Convention Abstract, Calgary, Alberta, Canada, 1-5.

[20] Egbobawaye, E.I. (2013) Tight Gas Reservoir Characterization in Montney Formation, Northeastern British Columbia, 
Western Canada. Doctor of Philosophy Thesis, Department of Earth and Atmospheric Sciences, University of Alberta, Edmonton, $431 \mathrm{p}$.

[21] McLean, F.H. and Kindle, E.D. (1950) Geology of Northeast British Columbia. Geological Survey of Canada, Memoir, 259.

[22] Hunt, A.D. and Ratcliffe, J.D. (1959) Triassic Stratigraphy, Peace River Area, Alberta and British Columbia, Canada. AAPG Bulletin, 43, 563-589.

[23] Armitage, J.H. (1962) Triassic Oil and Gas Occurrences in Northeastern British Columbia, Canada. Journal of the Alberta Society of Petroleum Geologists, 10, 35-56.

[24] Gibson, D.W. and Barclay, J.E. (1989) Middle Absaroka Sequence, the Triassic stable Craton. In: Ricketts, B.D., Ed., Western Canada Sedimentary Basin: A Case History, Canadian Society of Petroleum Geologists, 219-231.

[25] Gibson, D.W. and Edwards, D.E. (1990) An Overview of Triassic Stratigraphy and Depositional Environments in the Rocky Mountain Foothills and Western Interior Plains, Peace River Arch Area. Bulletin of Canadian Petroleum Geology, 38A, 146-158.

[26] Moslow, T.F. and Davies, G.R. (1992) Triassic Reservoirs Facies and Exploration Trends: Western Canada Sedimentary Basin, Canadian Society of Petroleum Geologists. American Association of Petroleum Geologists, Short Course, Calgary, Alberta, 166 p.

[27] Henderson, C.M. (1997) Uppermost Permian Conodont and Permian-Triassic Boundary in the Western Canada Sedimentary Basin. Bulletin of Canadian Petroleum Geology, 45, 693-707.

[28] Paull, R.K., Paull, R.A. and Laudon, T.S. (1997) Conodont Biostratigraphy of the Lower Triassic Mackenzie Dolomite Lentil, Sulphur Mountain Formation in the Cadomin Area, Alberta. Bulletin of Canadian Petroleum Geology, 45, 708-714.

[29] Richards, B.C. (1989) Upper Kaskaskia Sequence: Uppermost Devonian and Lower Carboniferous. In: Ricketts, B.D., Ed., Western Canada Sedimentary Basin-A Case History, Canadian Society of Petroleum Geologists, Special Publication No. 30, Calgary, Alberta, 165-201.

[30] Barclay, J.E., Krause, F.F., Campbell, R.I. and Utting, J. (1990) Dynamic Casting and Growth Faulting: Dawson Creek Graben Complex, Carboniferous-Permian Peace River Embayment, Western Canada. Bulletin of Canadian Petroleum Geology, 38A, 115-145.

[31] O’Connell, S.C., Dix, G.R. and Barclay, J.E. (1990) Origin, History, and Regional Structural Development of the Peace River Arch, Western Canada. Bulletin of Canadian Petroleum Geology, 38A, 4-24.

[32] Walsh, W., Adams, A., Kerr, B. and Korol, J. (2006) “Regional Shale Gas” Potential of the Triassic Doig and Montney Formations, Northeastern British Columbia. Ministry of Energy, Mines and Petroleum Resources, Oil and Gas Division, Resource Development and Geoscience Branch, British Columbia, Petroleum Geology Open File 2006-02, 19 p.

[33] Faraj, B., Williams, H., Addison, G., McKinstry, B., Donaleshen, R., Sloan, G., Lee, J., Anderson, T., Leal, R., Anderson, C., Lafleur, C. and Ahlstrom, J. (2002) Shale Potential of Selected Upper Cretaceous, Jurassic, Triassic and Devonian Shale Formations, in the WCSB of Western Canada: Implications for Shale Gas Production. A Report for Gas Technology Institute (GTI), Des Plains, Illinois, USA.

[34] Reidiger, C.L., Fowler, M.G., Brooks, P.W. and Snowdon, L.R. (1990) Triassic Oils and Potential Mesozoic Source Rocks, Peace River Arch Area, Western Canada Basin. Organic Geochemistry, 16, 295-305. http://dx.doi.org/10.1016/0146-6380(90)90049-6

[35] Egbobawaye, E.I., Zonneveld J.-P. and Gingras, M.K. (2010) Tight Gas Reservoir Evaluation in Montney and Lower Doig Formations, Northeastern British Columbia, Western Canada. American Association of Petroleum Geologists Abstract, 19, 66-67.

[36] Orchard, M.J. and Zonneveld, J.-P. (2009) The Lower Triassic Sulphur Mountain Formation in the Wapiti Lake Area: Lithostratigraphy, Conodont Biostratigraphy, and a New Biozonation for the Lower Olenekian (Smithian). Canadian Journal of Earth Sciences, 46, 757-790. http://dx.doi.org/10.1139/E09-051

[37] Habicht, J.K.A. (1979) Paleoclimate, Paleomagnetism, and Continental Drift. American Association of Petroleum Geologists Studies in Geology, 9, 1-29.

[38] Tozer, E.T. (1982) Marine Triassic Faunas of North America: Their Significance for Assessing Plate and Terrane Movements. Geologische Rundschau, 71, 1077-1104. http://dx.doi.org/10.1007/BF01821119

[39] Arnold, K.J. (1994) Origin and Distribution of Eolian Sandstones in the Triassic Charlie Lake Formation, Northeastern British Columbia. Unpublished M.Sc. Thesis, University of Alberta, Edmonton, 320 p.

[40] Porter, J.W., Price, R.A. and McCrossan, R.G. (1982) The Western Canada Sedimentary Basin. Philosophical Transactions of the Royal Society of London, A305, 169-182. http://dx.doi.org/10.1098/rsta.1982.0032

[41] Price, R.A. (1979) Intracontinental Ductile Crustal Spreading Linking the Fraser River and Northern Rocky Mountain 
Trench Transform Fault Zones. Geological Society of America, Programs with Abstracts, 11, 499.

[42] Monger, J.W.H. and Price, R.A. (1979) Geodynamic Evolution of the Canadian Cordillera—Progress and Problems. Canadian Journal of Earth Sciences, 16, 770-791. http://dx.doi.org/10.1139/e79-069

[43] Wittenberg, J. and Moslow, T.F. (1991) Origin and Variability of Over Thickened Sandstone in the Doig Formation, West-Central Alberta. Canadian Society of Petroleum Geologists, Calgary, 146.

[44] Cant, D.J. (1986) Hydrocarbon Trapping in the Halfway Formation (Triassic), Wembley Field, Alberta. Bulletin of Canadian Petroleum Geology, 34, 329-338.

[45] Berger, Z., Boast, M. and Mushayandebvu, M. (2009) Basement Structures Control on the Development of the Peace River Arch’s Montney/Doig Resource Plays. Canadian Society of Petroleum Geologists, 36, 40-45.

[46] Jarvis, I. and Jarvis, K.E (1992) Plasma Spectrometry in the Earth Sciences: Techniques and Future Trends. Chemical Geology, 95, 1-33. http://dx.doi.org/10.1016/0009-2541(92)90041-3

[47] Tucker, M., Ed. (1988) Techniques in Sedimentology. Blackwell Scientific Publication, 393 p.

[48] Sorby, H.C. (1858) On the Microscopic Structure of Crystals, Indicating the Origin of Minerals and Rocks. Quarterly Journal of the Geological Society of London, 14, 453-500. http://dx.doi.org/10.1144/GSL.JGS.1858.014.01-02.44

[49] Bone, Y., James, N.P. and Kyser, T.K. (1992) Synsedimentary Detrital Dolomite in Quaternary Cool-Water Carbonate Sediments, Lacepede Shelf, South Australia. Geology, 20, 109-112. http://dx.doi.org/10.1130/0091-7613(1992)020<0109:SDDIQC>2.3.CO;2

[50] Weaver, C.E. (1959) The Clay Petrology of Sediments. Clays Mineral, Proc. Natural Conference, Minerals, 6, 154187.

[51] Weaver, C.E. (1960) Possible Uses of Clay Minerals in the Search for Oil. AAPG Bulletin, 44, 1505-1518. http://dx.doi.org/10.1016/b978-0-08-009351-2.50024-6

[52] Frey, M. (1970) The Step from Diagenesis to Metamorphism in Pelitic Rocks during Alpine Orogenesis. Sedimentology, 15, 261-279. http://dx.doi.org/10.1111/j.1365-3091.1970.tb02189.x

[53] Gill, W.D., Khalaf, F.E. and Massoud, M.S. (1977) Clay Minerals as an Index of the Degree of Metamorphism of the Carbonate and Terrigeneous Rocks in the South Wales Coalfield. Sedimentology, 39, 330-332.

[54] Stalder, P.J. (1970) Organic and Inorganic Metamorphism in the Taveyyannaz Sandstone of Swiss Alps and Equivalent Sandstones in France and Italy. Journal of Sedimentary Petrology, 49, 463-482.

[55] Burst, J.F. (1969) Diagenesis of Gulf Coast Clayey Sediments and Its Possible Relation to Petroleum Migration. American Association of Petroleum Geologists Bulletin, 53, 73-93.

[56] England, G.L., Rasmussen, B., Krapez, B. and Groves, D.I. (2002) Palaeoenvironmental Significance of Rounded Pyrite in Siliciclastic Sequences of the Late Archean Witwatersrand Basin: Oxygen-Deficient Atmosphere or Hydrothermal Alteration? International Association of Sedimentologists, 49, 1133-1156.

[57] Hudson, J.D. (1982) Pyrite in Ammonite-Bearing Shales from the Jurassic of England and Germany. International Association of Sedimentologists, 37, 639-667. http://dx.doi.org/10.1111/j.1365-3091.1982.tb00072.x

[58] Kennedy, M.J., Pevear, D.R. and Hills, R.J. (2002) Mineral Surface Control of Organic Carbon in Black Shale. Science, 295, 657-660. http://dx.doi.org/10.1126/science.1066611

[59] Raitzsch, M., Völker, D. and Heubeck, C. (2007) Neogene Sedimentary and Mass Wasting Processes on the Continental Margin off South-Central Chile Inferred from Dredging Samples. Marine Geology, 244, 166-183. http://dx.doi.org/10.1016/j.margeo.2007.06.007

[60] Einsele, G. (2000) Sedimentary Basins: Evolution, Facies, and Sediment Budget. Springer-Verlag, Berlin, Heidelberg, 791 p. http://dx.doi.org/10.1007/978-3-662-04029-4

[61] Carson, B. and Arcaro, N.P. (1983) Control of Clay Mineral Stratigraphy by Selective Transport in Late Pleistocene-Holocene Sediments of Northern Cascadia Basin_-Juan de Fuca Abyssal Plain: Implication for Studies of Clay Mineral Provenance. Journal of Sedimentary Petrography, 53, 395-406.

[62] Gibbs, R.J. (1985) Settling Velocity, Diameter, and Density for Flocs of Illite, Kaolinite and Montmorillonite. Journal of Sedimentary Petrography, 55, 65-68.

[63] Lamy, F., Hebbeln, D. and Wefer, G. (1998) Terrigeneous Sediment Supply along the Chilean Continental Slope: Modern Latitudinal Trends of Texture and Composition. Geologische Rundschau, 87, 477-494. http://dx.doi.org/10.1007/s005310050223

[64] Jarvis, I. and Higgs, N. (1987) Trace Element Mobility during Early Diagenesis in Distal Turbidites: Late Quaternary of the Madeira Abyssal Plain, N. Atlantic. Geological Society, London, Special Publications, 31, 179-214. http://dx.doi.org/10.1144/GSL.SP.1987.031.01.14

[65] Froelich, P.N., Klinkhammer, G.P., Bender, G.R., Luedtke, N.A., Heath, G.R., Cullen, D., Dauphine, P., Hammond, D. 
and Hartman, B. (1979) Early Oxidation of Organic Matter in Pelagic Sediments of the Eastern Equatorial Atlantic: Suboxic Diagenesis. Geochimica et Cosmochimica Acta, 43, 1075-1090.

http://dx.doi.org/10.1016/0016-7037(79)90095-4

[66] Klinkhammer, G.P. (1980) Early Diagenesis in Sediments from the Eastern Equatorial Pacific, II. Porewater Metal Results. Earth Planetary Science Letter, 49, 81-101. http://dx.doi.org/10.1016/0012-821X(80)90151-X

[67] Burbidge, D.J. and Gieskes, J.M. (1983) A Porewater Solid Phase Diagenetic Model for Manganese in Marine Sediments. American Journal of Science, 283, 29-47. http://dx.doi.org/10.2475/ajs.283.1.29

[68] Bonatti, E., Fisher, D.E., Joensuu, O. and Rydell, H.S. (1971) Postdepositional Mobility of Some Transitional Elements, Phosphorous, Uranium and Thorium in Deep Sea Sediments. Geochimica et Cosmochimica Acta, 35, 18151819. http://dx.doi.org/10.1016/0016-7037(71)90057-3

[69] Sawlan, J.J. and Murray, J.W. (1983) Trace Element Mobilization in the Interstitial Waters of Red Clay and Hemipelagic Marine Sediments. Earth Planetary Science Letter, 64, 213-230. http://dx.doi.org/10.1016/0012-821X(83)90205-4

[70] Kodo, D. and Heath, G.R. (1984) Models of Depth Dependent Bioturbation at MANOP Site H in the Eastern Equatorial Pacific. Journal of Geophysical Research, 89, 6567-6570. http://dx.doi.org/10.1029/JC089iC04p06567

[71] Stamatiakis, M.G. (2003) Phosphate Deposits of Neogene Age in Greece. Mineralogy, Geochemistry and Genetic Implications. Chemistry, 64, 329-357.

[72] Cox, P.A. (1997) The Elements on Earth. Inorganic Chemistry in the Environment. Oxford University Press, Oxford, $284 \mathrm{p}$.

[73] Chen, Z., Huang, C.-Y., Zhao, M.X., Yan, W., Chien, C.-W., Chen, M.H., Yang, H.P., Machiyama, H. and Lin, S. (2010) Characteristics and Possible Origin of Native Aluminum in Cold Seep Sediments from the Northeastern South China. Journal of Asian Earth Sciences, 40, 363-370. http://dx.doi.org/10.1016/j.jseaes.2010.06.006

[74] Iyer, S.D., Mascarenhas-Pereira, M.B.L. and Nath, B.N. (2007) Native Aluminum (Spherules and Particles) in the Central Indian Basin Sediments: Implications on the Occurrence of Hydrothermal Events. Marine Geology, 240, 177184. http://dx.doi.org/10.1016/j.margeo.2007.02.004

[75] Dekov, V.M., Mandova, E.D., Dimitrov, K.C. and Rekkalov, K.N. (1995) Native Aluminum in Metalliferous Sediments from the East Pacific Rise Axial Zone (21 S). Marine Geology, 123, 87-103. http://dx.doi.org/10.1016/0025-3227(95)80006-W

[76] Howard, K.J. and Fisk, M.R. (1988) Hydrothermal Alumina-Rich Clays and Boehmite on the Gorda Ridge. Geochimica et Cosmochimica Acta, 52, 2269-2279. http://dx.doi.org/10.1016/0016-7037(88)90129-9

[77] Novgorodova, M.I. and Mamedov, Y.G. (1996) Native Aluminum from Mud Volcano at the Bulla Island, Caspian Sea. Lithology and Mineral Resources, 31, 301-310.

[78] Yang, K. and Scott, S.D. (1996) Possible Contribution of a Metal-Rich Magmatic Fluid to A Sea-Floor Hydrothermal System. Nature, 383, 420-423. http://dx.doi.org/10.1038/383420a0

[79] Rubin, K. (1997) Degassing of Metals and Metalloids from Erupting Seamount and Mid-Ocean Ridge Volcanoes: Observations and Predictions. Geochimica et Cosmochimica Acta, 61, 3525-3542. http://dx.doi.org/10.1016/S0016-7037(97)00179-8

[80] Stolyarov, I.S., Silenko, T.M., Ryabeva, Y.G. and Yurkina, K.V. (1988) Al from the Ukachilkan Tin Deposit, Northeastern Yakutia. International Geological Review, 10, 1136-1140. http://dx.doi.org/10.1080/00206818809466094

[81] Deng, Y., Zhang, L., Ou, J. and Zhang, H. (1983) Discovery of Native Aluminum in Fault Zones of Granodiorite. Journal of Guilin Institute of Technology, No. 1, 1-6.

[82] Banerjee, D.M. and Saigal, N. (1988) A Study of Proterozoic Phosphorite from Chelima-Pachcherla Area, Kurnool District, Andhra Pradesh, India. Journal of Geological Society of India, 32, 32-39.

[83] Leckie, J.O. and Davis, J.A. (1979) Aqueous Environmental Chemistry of Copper. In: Nriagu, J.O., Ed., Copper in the Environment, Wiley, New York, 90-121.

[84] Gao, H.Z. (1998) The Biochemical Sedimentary Metallogenic Model of Baritic and Witheritic Deposits in Lower Cambrian in China. Journal of Mineralogy and Petrology, 18, 70-77.

[85] Huba, C., Remacle, J., Dubois, D. and Thorez, J. (1983) Factors Affecting the Concentrations of Cadmium, Zinc, Copper and Lead in the Sediments of the Vesdre River (Belgium). Water Research, 17, 1281-1286. http://dx.doi.org/10.1016/0043-1354(83)90253-1

[86] Li, Y.-H., Burkhardt, L. and Teraoka, H. (1984) Desorption and Coagulation of Trace Elements during Estuarine Mixing. Geochimica et Cosmochimica Acta, 48, 1879-1884. http://dx.doi.org/10.1016/0016-7037(84)90371-5

[87] Paris, G., Bartolini, A., Donnadieu, Y., Beaumont, V. and Gaillardet, J. (2010) Investigating Boron Isotopes in a Middle Jurassic Micritic Sequence: Primary vs. Diagenetic Signal. Chemical Geology, 275, 117-126. http://dx.doi.org/10.1016/j.chemgeo.2010.03.013 
[88] Vengosh, A., Chivas, A.R., McCulloch, M.T., Tarinsky, A. and Kolodny, Y. (1991) Boron Isotope Geochemistry of Australian Salt Lakes. Geochimica et Cosmochimica Acta, 55 2591-2606. http://dx.doi.org/10.1016/0016-7037(91)90375-F

[89] Hemming, N.G. and Hanson, G.N. (1992) Boron Isotopic Composition and Concentration in Modern Marine Carbonates. Geochemica et Cosmochimica Acta, 56, 537-543. http://dx.doi.org/10.1016/0016-7037(92)90151-8

[90] Lemarchand, D., Gaillardet, J., Lewin, E. and Allègre, C.J. (2000) The Influence of Rivers on Marine Boron Isotopes and Implications for Reconstructing Past Ocean pH. Nature, 408, 951-954. http://dx.doi.org/10.1038/35050058

[91] Joachimski, M.M., Simon, L., van Geldern, R. and Lécuyer, C. (2005) Boron Isotope Geochemistry of Paleozoic Brachiopod Calcite: Implications for a Secular Change in the Boron Isotope Geochemistry of Seawater over the Phaneozoic. Geochimica et Cosmochimica Acta, 69, 4035-4044. http://dx.doi.org/10.1016/j.gca.2004.11.017

[92] Simon, L., Lécuyer, C., Maréchal, C. and Coltice, N. (2006) Modelling the Geochemical Cycle of Boron: Implications for the Long-Term $\delta^{11} \mathrm{~B}$ Evolution of Seawater and Oceanic Crust. Chemical Geology, 225, 61-76. http://dx.doi.org/10.1016/j.chemgeo.2005.08.011

[93] Spivack, A.J., Palmer, M.R. and Edmond, J.M. (1987) The Sedimentary Cycle of the Boron Isotopes. Geochimica et Cosmochimica Acta, 51, 1939-1949. http://dx.doi.org/10.1016/0016-7037(87)90183-9

[94] You, C.F., Spivack, A.J., Gieskes, J.M., Rosenbauer, R. and Bischoff, J.L. (1995) Experimental Study of Boron Geochemistry: Implications for Fluid Processes in Subduction Zones. Geochimica et Cosmochimica Acta, 59, $2435-2442$.

[95] Berner, R.A. (1973) Phosphate Removal from Sea Water by Adsorption on Volcanogenic Ferric Oxides. Earth and Planetary Science Letters, 18, 77-86. http://dx.doi.org/10.1016/0012-821X(73)90037-X

[96] Hem, J.D. (1972) Chemistry and Occurrence of Cadmium and Zinc in Surface Water and Ground Water. Water Resource Research, 8, 661-679. http://dx.doi.org/10.1029/WR008i003p00661

[97] Callender, E. and Bowser, C.J. (1980) Manganese and Copper Geochemistry of Interstitial Fluids from Manganese Nodule-Rich Pelagic Sediments of the Northeastern Equatorial Pacific Ocean. American Journal of Science, 280, 1063-1096. http://dx.doi.org/10.2475/ajs.280.10.1063

[98] Klinkhammer, G.P. (1980) Early Diagenesis in Sediments from the Eastern Equatorial Pacific. II. Porewater Metal Results. Earth and Planetary Science Letters, 49, 81-101. http://dx.doi.org/10.1016/0012-821X(80)90151-X

[99] Sawlan, J.J. and Murray, J.W. (1983) Trace Element Mobilization in the Interstitial Waters of Red Clay and Hemipelagic Marine Sediments. Earth and Planetary Science Letters, 64, 213-230. http://dx.doi.org/10.1016/0012-821X(83)90205-4

[100] Heggie, D. and Lewis, T. (1984) Cobalt in Pore Waters of Marine Sediments. Nature, 311, 453-455. http://dx.doi.org/10.1038/311453a0

[101] Holland, H.D. (1978) The Chemistry of the Atmosphere and Oceans. Wiley-Interscience, New York.

[102] de Dolomieu, D.G. (1791) Sur un de pierrestrés-peueffervescentes avec les acides of phosphorescentes par la collision. Journal de Physique, 39, 3-10.

[103] Land, L.S. (1983) The Application of Stable Isotopes to Studies of the Origin of Dolomite and Problems of Diagenesis of Clastic Sediments. In: Arthur, M.A., et al., Eds., Stable Isotope in Sedimentary Geology, Vol. 10, SEPM Short Course, 4.1-4.22.

[104] Graf, D.L. and Goldsmith, J.R. (1956) Some Hydrothermal Syntheses of Dolomite and Protodolomite. Journal of Geology, 64, 173-186. http://dx.doi.org/10.1086/626332

[105] Goldsmith, J.R. and Heard, C.D. (1961) Subsolidus Phase Relations in the System $\mathrm{CaCO}_{3}-\mathrm{MgCO}_{3}$. Journal of Geology, 69, 45-74. http://dx.doi.org/10.1086/626715

[106] Degens, E.T. (1967) Diagenesis of Organic Matter. In: Larsen, G. and Chilingar, G.V., Eds., Diagenesis of Sediments, Elsevier Publishing Co., New York, 343-390. http://dx.doi.org/10.1016/S0070-4571(08)70846-X

[107] Dapples, E.C. (1967) Diagenesis in Sandstones. In: Larsen, G. and Chilingar, G.V., Eds., Diagenesis of Sediments, Elsevier Publishing Co., New York, 91-125. http://dx.doi.org/10.1016/S0070-4571(08)70842-2

[108] Weller, J.M. (1959) Compaction, of Sediments. American Association of Petroleum Geologists, 43, $273-310$.

[109] Von Engelhardt, W. and Gaida, K.H. (1963) Concentration Changes of Pore Solutions during the Compaction of Clay Sediments. Journal of Sedimentary Petrography, 33, 919-930. http://dx.doi.org/10.1306/74D70F74-2B21-11D7-8648000102C1865D

[110] Müller, G. (1967) Diagenesis in Argillaceous Sediments. In: Larsen, G. and Chilingar, G.V., Eds., Diagenesis of Sediments, Elsevier Publishing Co., New York, 128-177. http://dx.doi.org/10.1016/S0070-4571(08)70843-4 